\title{
The cascudos of the genus Hypostomus Lacépède (Ostariophysi: Loricariidae) from the rio Iguaçu basin
}

\author{
Julio César Garavello ${ }^{1}$ Heraldo Antônio Britski ${ }^{2}$ and Claudio Henrique Zawadzki ${ }^{3}$
}

\begin{abstract}
We reviewed several large collections of the genus Hypostomus from the rio Iguaçu basin summing up to 793 specimens mainly from the Laboratório de Ictiologia do Departamento de Ecologia e Biologia Evolutiva from Universidade Federal de São Carlos, from fish collection of Núcleo de Pesquisas em Limnologia, Ictiologia e Aquicultura da Universidade Estadual de Maringá, and from the Museu de História Natural do Capão da Imbuia. Hypostomus albopunctatus, H. commersoni, H. derbyi, and $H$. myersi are redescribed and Hypostomus nigropunctatus is described as a new species. A practical key for identification of Hypostomus species from the rio Iguaçu is also provided.
\end{abstract}

Foram revisadas extensivas coleções de peixes do gênero Hypostomus da bacia do rio Iguaçu, somando 793 exemplares, principalmente das seguintes coleções: Laboratório de Ictiologia do Departamento de Ecologia e Biologia Evolutiva da Universidade Federal de São Carlos, da coleção de peixes do Núcleo de Pesquisas em Limnologia, Ictiologia e Aquicultura da Universidade Estadual de Maringá e do Museu de História Natural do Capão da Imbuia. Hypostomus albopunctatus, $H$. commersoni, $H$. derbyi e $H$. myersi são redescritas e Hypostomus nigropunctatus é descrita como uma espécie nova. Uma chave artificial de identificação para as espécies do gênero Hypostomus do rio Iguaçu também é fornecida.

Key words: Hypostominae, Neotropical fishes, Systematics, Taxonomy.

\section{Introduction}

This review of Hypostomus from the rio Iguaçu basin was conducted as part of a larger effort to revise the taxonomy of genus from the whole rio Paraná hydrographic system. Catfishes of the genus Hypostomus are benthic and have a broad distribution across most aquatic habitats in tropical South American river basins. According to Weber (2003) the greatest species richness of Hypostomus comes from the Paraná-Paraguay basin.

The rio Iguaçu is a tributary of the rio Paraná in southern Brazil and there has been considerable confusion regarding the species of Hypostomus that occur there. The rio Iguaçu basin has near $1.080 \mathrm{~km}$ of extension declining almost 830 meters from its origins to Cataratas do Iguaçu. Its headwaters are located in Serra do Mar near Curitiba in a region geologically known as First Paranean Plateau, the rio Iguaçu between Engenheiro Blay and Porto Amazonas cities, includes fast and extensive rapids attached with ample flooded areas, marking the known route to the Second Paranean Plateau. At this place, Maack (1981) identified their beds dated from Devonian times. Continuing downriver, when running through
Serra da Boa Esperança it ingress to Third Paranean Plateau, an area geologically dated from Tertiary beds. Again, it includes rapids and waterfalls in cascade to get the Cataratas do Iguaçu in Brazil, just before to flows into the rio Paraná just downstrem Itaipu reservoir. The water volume greatly varies along the year, depending of rainfalls and according to Maack (1981) the rio Iguaçu was characterized by rich vegetation of araucaria trees (Araucaria angustifolia) in the past. Meanwhile, the forest devastation was so hard in the middle 1960's when nearly $2 / 3$ of those forests were removed and succeeded by secondary vegetation or agriculture. The places where the Hypostomus species were collected in rio Iguaçu usually include extensive waterfalls and rapids which are variable in depth, but most frequently with rocky bottom forming torrential environments.

The first Hypostomus species described from the rio Paraná system was Hypostomus commersoni Valenciennes, 1836 with type locality given as La Plata (Argentina) and rio São Francisco (Brazil). A second species, Hypostomus auroguttatus Kner, 1854, was described with only "Brasil Oriental” given as the type locality. Miranda Ribeiro (1918) determined that the type locality for this species was probably

${ }^{1}$ Universidade Federal de São Carlos, Departamento de Ecologia e Biologia Evolutiva, Caixa Postal 676, 13.565-905 São Carlos, SP, Brazil. garavelo@ufscar.br

${ }^{2}$ Museu de Zoologia da Universidade de São Paulo, Seção de Peixes, Caixa Postal 7172, 01064-970 São Paulo, SP, Brazil. heraldo@usp.br ${ }^{3}$ Universidade Estadual de Maringá, Departamento de Biologia/Nupélia, Av. Colombo, 5790, 87020-900 Maringá, PR, Brazil. chzawadzki@hotmail.com 
in the Mogi-Guaçu and Tietê river basins in São Paulo State, Brazil. Hypostomus emarginatus Valenciennes, 1840 was also described with only "Brasil" given as the type locality, but this species, along with $H$. alatus Castelnau (type locality: Sabará, Minas Gerais) and H. garmani Regan (type locality: rio das Velhas, São Francisco basin) were all recorded from the Tietê, Pardo, and Piracicaba river basins by Miranda Ribeiro (1918). It seems likely that these were all misidentifications since the author did not provide a list of examined material and none of these species have been observed in the upper rio Paraná basin since then (Langeani et al., 2007). Ihering (1905, 1911), Regan (1908), and Gosline (1945) all made major contributions to the systematics of Hypostomus in the upper rio Paraná basin; however, at no point has the taxonomy of this fauna been reviewed.

Ihering (1905) described Plecostomus hermanni, P. paulinus, and $P$. regani based on specimens from the rio Piracicaba and $P$. tietensis from the upper stretches of the rio Tietê basin and Regan (1908) described $P$. albopunctatus, $P$. iheringii, $P$. margaritifer, and $P$. strigaticeps, also from the rio Piracibaba. Thereafter, Ihering (1911) described P. ancistroides from Tietê basin and P. lexi, P. margaritifer butantanis, and $P$. variipictus from Mogi-Guaçu river basins. Marini et al. (1933) described P. meleagris and P. niger from rio Mogi-Guaçu, based on specimens sent by Ihering from Pirassununga and, finally, Nichols (1919) described $P$. scaphyceps from Cerqueira Cesar (all localities at São Paulo State).

In the rio Iguaçu basin, Haseman (1911) described Plecostomus derbyi and in his revision of loricariid ichthyofauna from southeastern Brazil, Gosline (1945) described Hypostomus myersi, both species coming from União da Vitória, Paraná State. Since this time no more Hypostomus species have been described from rio Iguaçu basin. However, the rio Iguaçu fish fauna is also known to include $H$. albopunctatus (Regan) and $H$. commersoni Valenciennes (Zawadzki et al., 1999, 2001), plus another undescribed and probably endemic species.

Herein, we examined 793 specimens of Hypostomus from rio Iguaçu deposited in the Laboratório de Ictiologia do Departamento de Ecologia e Biologia Evolutiva from Universidade Federal de São Carlos, from fish collection of Núcleo de Pesquisas em Limnologia, Ictiologia e Aquicultura da Universidade Estadual de Maringá, and from the Museu de História Natural do Capão da Imbuia. The four nominal species of Hypostomus from rio Iguaçu are redescribed and Hypostomus nigropunctatus is described as new. We provide a key for the identification of Hypostomus species from the rio Iguaçu and an appraisal of all Hypostomus species present in rio Iguaçu basin.

\section{Material and Methods}

From the examined material, meristic and morphometric data were obtained point-to-point with a $0.01 \mathrm{~mm}$ digital caliper according to procedures of Boeseman (1968) and Weber (1985). Counts were obtained for all fins, teeth, and plates and are included with the descriptions of species. Bone and plate nomenclature follow Schaefer (1997). Other qualitative data, e.g. color pattern, teeth design, position of abdominal plates, were examined in a comparative manner and are included with the descriptions of species. The morphometric data of Hypostomus tapijara used in the diagnosis of $H$. commersoni was those from Oyakawa et al. (2005).

Institutional abbreviations are: AMNH, American Museum of Natural History, New York; ANSP, Academy of Natural Sciences of Philadelphia, Philadelphia; BMNH, British Museum of Natural History, London; LISDEBE, Laboratório de Ictiologia do Departamento de Ecologia e Biologia Evolutiva, Universidade Federal de São Carlos, São Carlos; MHNCI, Museu de História Natural Capão da Imbuia, Curitiba; MHNG, Museum d'Histoire Naturelle, Geneve; MNHN, Museum National d'Histoire Naturelle, Paris; MNRJ, Museu Nacional, Rio de Janeiro; MZUSP, Museu de Zoologia da Universidade de São Paulo, São Paulo; NUP, Núcleo de Pesquisas em Limnologia, Ictiologia e Aquicultura, Universidade Estadual de Maringá, Maringá. In the collector section of listed material, Copel, Gerpel, Lisdebe-UFSCar, Nupélia and Surehma refer to the ichthyology collections staff at each institution.

\section{Key for the species of the genus Hypostomus from rio Iguaçu basin.}

1. Head wide and depressed; usually no keels or thin odontode rows along the lateral plate series. Dark brown with numerous pale spots on head, trunk and fins ..................... 2

1 '. Head high and compressed; at least one moderate to strong keels along lateral series of plates. Black spots on head, trunk and fins .

2. Large number of slender teeth on premaxilla (65 to 89) and dentary (64 to 90); pectoral-fin unbranched ray longer than pelvic-fin unbranched ray ....................... Hypostomus myersi

2'. Moderate number of robust teeth on premaxilla (26 to 51) and dentary (26 to 44); pectoral-fin unbranched ray equal to or smaller in length than pelvic-fin unbranched ray . Hypostomus albopunctatus

3. Four series of keels supporting hypertrophied odontodes along lateral region of trunk; supraoccipital keel present. Ground color of head, trunk and abdomen conspicuously gray . .Hypostomus commersoni

3'. Just one partially keeled series, the median series, which is angled to about the sixtieth plate, but not supporting hypertrophied odontodes; supraoccipital lacking keel. Ground color dark brown uniform ......................................... 4

4. Ground color uniformly brown with mid-sized and moderately densely distributed dark spots (approximately equal in size to eye diameter) on dorsal region of head, trunk, and fins. Usually one pre-dorsal plate bordering supraoccipital Hypostomus derbyi

4'. Ground color uniformly brown with small-sized and closeset dark spots (equal to or smaller than pupil of the eye) on dorsal region of head, trunk, and fins. Three predorsal plates bordering supraoccipital ...... Hypostomus nigropunctatus 


\section{Hypostomus albopunctatus (Regan, 1908) Fig. 1}

Plecostomus albopunctatus Regan, 1908:797-798, fig. 206, pl. 49, fig.1 (type locality: rio Piracicaba, São Paulo, Brazil); Eigenmann, 1910:407 (ref.); Miranda Ribeiro, 1918:714 (Salto de Pirassununga, rio Mogi-Guaçu; rio Paraná; Piracicaba); Gosline, 1945:81 (ref.); Fowler, 1954:175 (rio Paraná, São Paulo).

Hypostomus albopunctatus: Isbrucker, 1980:18; Gomez \& Somay, 1989:726 (rio Iguazu, Argentina); López \& Miquelarena, 1991:18 (redesc.); Garavello et al., 1997:78 (rio Iguaçu); Weber, 1987:279 lectotype designation, BMNH 1907.7.6.15(seen); Weber, 2003:355 (ref.); Zawadzki et al., 2005:272 (upper rio Paraná - allozymes); Baumgartner et al., 2006:2 (Salto Osório reservoir, rio Iguaçu; check list); Carvalho \& Bockmann, 2007:92 (upper rio Paraná).

Material examined. All from Brazil: São Paulo State: BMNH 1907.7.6.15, 2, 134.1-169.0 mm SL, syntypes, rio Piracicaba. Paraná State: LISDEBE 2649, 4, 108.0-230.0 mm SL, rio Iguaçu, Salto Segredo reservoir, Municipality of Mangueirinha, Apr 1993, Nupélia. LISDEBE 2650, 11, 95.0-110.2 mm SL, rio Iguaçu, downstream Salto Santiago reservoir, Municipality of Laranjeiras do Sul, 2538'S 52³7’W, 11 Nov 1990, J. C. Garavello et al. MHNCI 7177, $260.5 \mathrm{~mm}$ SL, rio Iguaçu, Municipality of Nova Prata do

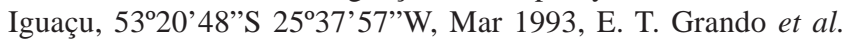
MHNCI 11737, 4, 127.2-180.5 mm SL, rio Três Barras, Municipality of Três Barras do Paraná, 25 Feb 1993, E. T. Grando et al. MHNCI 11738, 2, 182.0-202.6 mm SL, rio Guarani, Municipality of Três Barras do Paraná, $25^{\circ} 25^{\prime} 08^{\prime \prime} \mathrm{S} 53^{\circ} 10^{\prime} 50^{\prime \prime} \mathrm{W}$, 23 Feb 1993, E. T. Grando et al. MHNCI 11741, 1, 194.0 mm SL, rio Iguaçu, Municipality of Nova Prata do Iguaçu, 2537'57"S 5320’48”W, 22 Mar 1993, E. T. Grando et al. MHNCI 11742, 1, $166.0 \mathrm{~mm}$ SL, rio Iguaçu, Municipality of Nova Prata do Iguaçu, 5320'48”S 2537'57”'W, 22 Mar 1993, E. T. Grando et al. MHNCI 11745, 1, $183.7 \mathrm{~mm}$ SL, Salto Caxias reservoir, rio Iguaçu, Municipality of Capitão Leônidas Marques/Nova Prata do Iguaçu, 2530'S 53²4'W, 15 Aug 1994, E. T. Grando et al. NUP 593, 2, 82.2-180.2 mm SL, córrego Passo do Aterrado, tributary of rio Jordão, Municipality of Foz do Jordão, $25^{\circ} 45^{\prime}$ S $52^{\circ} 10^{\prime} \mathrm{W}$; 14 Oct 1995, Copel. NUP 681, 6, 252.0-310.0 mm SL, Salto Caxias reservoir, rio Iguaçu, Municipality of Capitão Leônidas Marques/ Nova Prata do Iguaçu, 2537’57”S 53²0’48”W, Feb 1997, Nupélia. NUP 684, 10, 88.3-227.3 mm SL, Salto Caxias reservoir, rio Iguaçu, Municipality of Capitão Leônidas Marques/Nova Prata do Iguaçu, 2532'12”'S 5329'11”'W, 2 Sep 1997, Nupélia. NUP 1785, 8, 127.8$220.2 \mathrm{~mm}$ SL, Salto Caxias reservoir, rio Iguaçu, Municipality of Capitão Leônidas Marques/Nova Prata do Iguaçu, 2532'12"S 53²9’11”W, 20 Jan 1999, Nupélia. NUP 1830, 2, 81.7-225.3 mm SL, Salto Caxias reservoir, rio Iguaçu, Municipality of Capitão Leônidas Marques/Nova Prata do Iguaçu, 2532'12”'S 5329'11”W, 21-22 Apr 1996, Nupélia. NUP 4309, 17, 56.0-102.4 mm SL, riacho São João, Parque Nacional do Iguaçu, downstream Iguaçu waterfalls, rio Iguaçu, Municipality of Foz do Iguaçu, 12 Nov 2001, V. P. Margarido. NUP 4316, 21, 53.2-157.6 mm SL, riacho São João, Parque Nacional do Iguaçu, downstream Iguaçu waterfalls, rio Iguaçu, Municipality of Foz do Iguaçu, 1 Jun 2001, V. P. Margarido. NUP 5431, 1, 136.0 mm SL, Salto Caxias reservoir, rio Iguaçu, Municipality of Capitão Leônidas Marques/Nova Prata do Iguaçu,
25³2’12”S 53²9’11”W, 5 Mar 1997, Nupélia. NUP 5432, 2, 224.3$235.1 \mathrm{~mm}$ SL, Salto Caxias reservoir, rio Iguaçu, Municipality of Capitão Leônidas Marques/Nova Prata do Iguaçu, 25³2'12”S 53²9'11”W, Oct 1998, Nupélia. NUP 5786, 2, 167.7-198.6 mm SL, downstream Jordão reservoir, rio Jordão, tributary of rio Iguaçu, Municipality of Foz do Jordão/Reserva do Iguaçu, 2545'51"S 5205’23”W, 1 Jan 1998, Copel. NUP 5921, 1, 119.8 mm SL, downstream Salto Caxias reservoir, rio Iguaçu, Municipality of Capitão Leônidas Marques/Nova Prata do Iguaçu, 25³2'12”S 53²9’11”W, 3 Jul 1997, Nupélia. NUP 5931, 1, 116.8 mm SL, Salto Caxias reservoir, rio Iguaçu, Municipality of Capitão Leônidas Marques/Nova Prata do Iguaçu, 2532'12”S 53²9'11”W, 5 Mar 1997, Nupélia. Santa Catarina State: LISDEBE 2651, 1, 114.0 mm SL, rio Timbó, tributary of rio Iguaçu, colônia São Pedro, Municipality of Porto União, 2626'13”S 50 49'59”W, 18-19 Nov 1986, J. C. Garavello \& Surehma.

Diagnosis. Hypostomus albopunctatus can be distinguished from all other congeners except $H$. heraldoi by the pelvic-fin unbranched ray length equal to or greater than pectoral-fin unbranched ray (vs. pelvic-fin unbranched ray shorter than pectoral-fin unbranched ray). From $H$. heraldoi it is distinguished by having pale dots over body and fins (vs. dark dots over body and fins).

Description. Dorsal profile of head from tip of snout to beginning of supraoccipital almost straight; supraoccipital elevated; anterior plates of dorsal-fin insertion slightly concave. Head wide and depressed, totally covered by dermal bones with fine odontodes; a keel with origin at anterior nare, running over orbit and continuing back through pteroticsupracleithrum region and line of profuse odontodes along these keels. Snout wide and depressed. Mesethmoid forming inconspicuous keel from snout tip to upper region of orbit. Orbit narrow, almost dorsally positioned, $11.2-16.1 \%$ in head length. Posterior region of head between supraoccipital and dorsal-fin insertion formed by three unpaired and narrow predorsal plates; odontodes densely covering those plates not forming keels in posterior region of head.

Body profile almost straight from dorsal-fin insertion to caudal peduncle. Six interdorsal plates between dorsal fin and adipose fin. Adipose fin elevated and posteriorly curved inward. Upper region of caudal peduncle concave and lower region almost straight. Maximum body width at pectoral-fin insertion, gradually decreasing in a straight line to caudal fin. An unpaired nuchal plate in front of dorsal-fin insertion. Dorsal fin II,7; its origin slightly anterior to vertical through pelvic-fin insertion; far from reaching adipose-fin spine when adpressed; its distal border slightly convex. Pectoral fin I,6; first ray short, but reaching pelvic-fin insertion; covered by odontodes slightly larger than that of body covering; its distal border almost straight. Pelvic fin i,5; first ray elongate, surpassing half of anal fin in females; shorter in males; its distal border straight. Anal fin, i,5; distal border slightly rounded. Caudal fin i,14,i; forked, lower unbranched ray longer than upper.

Body covered by five longitudinal series of elongate plates; median series with origin at posterior region of scapular 


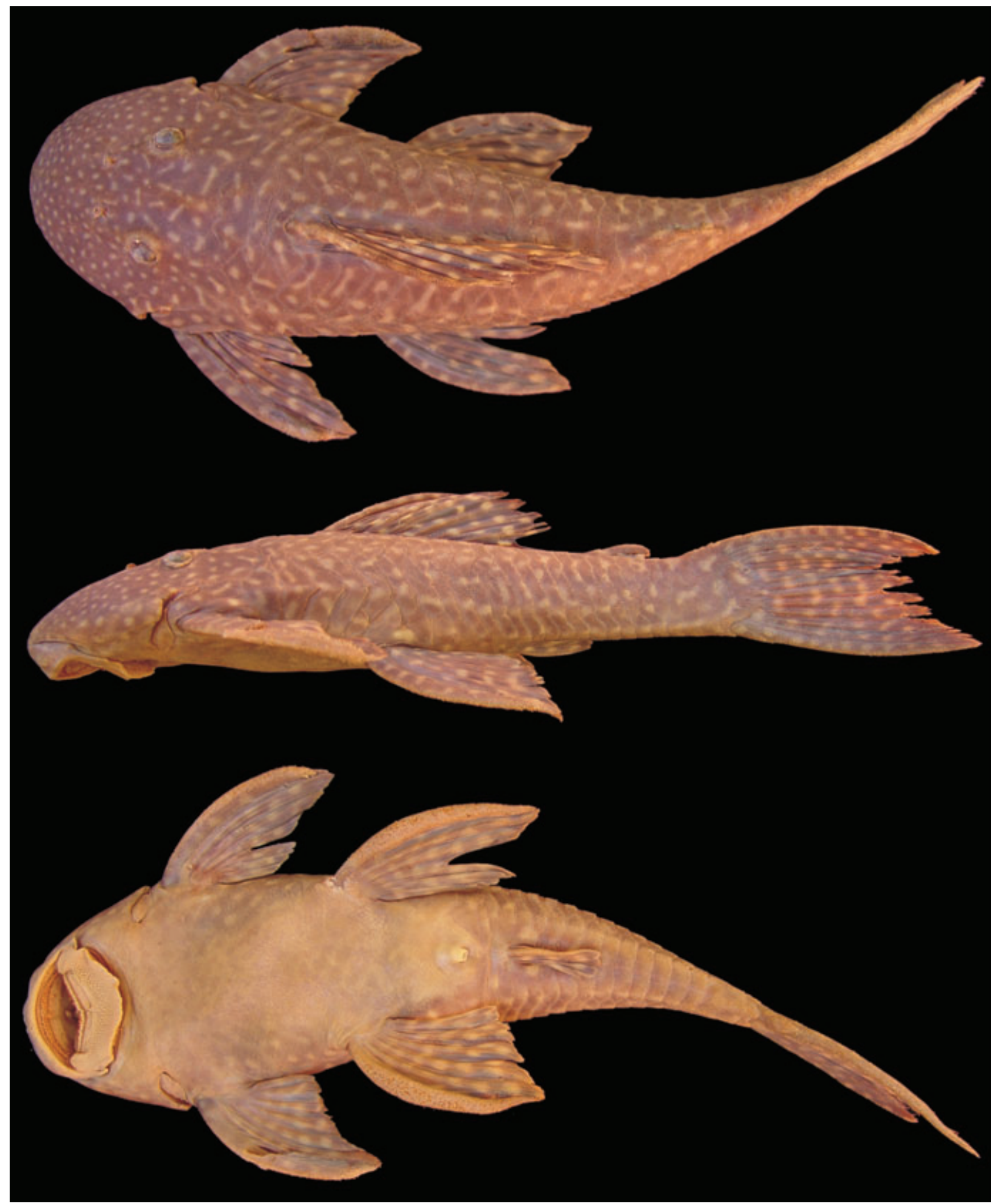

Fig. 1. Hypostomus albopunctatus, NUP 593, 108.2 mm SL, córrego Passo do Aterrado, tributary of rio Jordão, Municipality of Foz do Jordão, Paraná, Brazil. 
bridge and with inconspicuous keel running to caudal peduncle. Dorsal, mid-dorsal, middle and ventral series of plates without conspicuous keels. Mid-ventral series of plates angled just to pelvic-fin insertion region. Rostral margin of snout aciculate with dense irregular series of odontodes; tip of snout with a naked area at ventral region; irregular series of small dermal bones covering the snout from anterior region of orbit to limits of supraoccipital and pterotic-supracleithrum. Scapular bridge totally covered by skin; dense covering of small plates with odontodes on almost whole abdomen, even on juveniles; only a narrow naked area in front of anal opening; an unpaired plate between anus and the anal-fin insertion. Twenty eight plates in the lateral line. Lips gross and with dense papillae; a membrane joining the short and wide labial barbel to labial border. Premaxilla with 26 to 51, and dentary with 26 to 44 moderate to robust teeth; internal cusps shorter than external ones.

Color pattern. Ground color of head and trunk uniformly dark brown; head, trunk and fins with pale spots. Some specimens having spots on each lateral plate and on interradial membranes of all fins. Pale vermiculate spots on head and trunk forming conspicuous longitudinal rows along body and caudal peduncle in some specimens. Abdominal region light brown with dark brown spots or vermiculate on whole abdomen. Fins uniformly dark brown; unbranched rays of pelvic, anal and lower caudal fin light brown.

Distribution. Known from rio Paraná-Paraguay basin including rio Iguaçu. In the rio Iguaçu basin $H$. albopunctatus is found mainly in the main channel of the rio Iguaçu, from its upper stretches to the lower ones, including a population below Iguaçu Falls. It was also found in a few tributaries of the rio Iguaçu as the rio Três Barras and rio Guarani in the municipality of Três Barras; in the córrego Passo do Aterrado and rio Jordão at its mouth, both in the municipality of Foz do Jordão; and in the rio Timbó in the municipality of Porto União.

\section{Hypostomus commersoni Valenciennes, 1836} Fig. 2

Hypostomus commersoni Valenciennes, 1836:(266) 495-497 (type locality: rio de La Plata); Valenciennes, 1847:8 (ref.); Isbrucker, 1980:21 (ref.); Weber, 1986:994, rio da Prata (ref.); Reis et al., 1990:736 (lectotype, rio da Prata); López \& Miquelarena, 1991:20 (ref.); Garavello et al., 1997:79 (rio Iguaçu); Weber, 2003:357 (ref.); Zawadzki et al., 2005:272 (upper rio Paraná, allozymes); Carvalho \& Bockmann, 2007:92 (medium and lower rio Paraná, rio Uruguai).

Hypostomus aff. commersoni: Baumgartner et al., 2006:3 (Salto Osório reservoir, rio Iguaçu; check list).

Hypostomus aff. commersonii: Zawadzki et al., 1999:96 (allozymes and morphometrics); Zawadzki et al., 2001:914 (isozymes).

Plecostomus commersonii: Günther, 1864: 232 (rio Grande); Regan, 1904: 206 (rio da Prata); Miranda Ribeiro, 1907:188 (Iporanga, São Paulo); Eigenmann, 1910:404 (ref.); Nichols,
1918: 414 (São Paulo); Gosline, 1945: 78 (ref.); Fowler, 1954:179 (La Plata).

Plecostomus commersoni: Miranda Ribeiro, 1911:50 (rio

Paraná); Miranda Ribeiro, 1918:710 (São Paulo).

Material examined. Uruguay: rio de la Plata: MNHN A.9444, 425.0 mm SL, syntype. Brazil: Paraná State: LISDEBE 2652, 2, 147.0$193.0 \mathrm{~mm}$ SL, rio Iguaçu, Salto Segredo reservoir, Municipality of Mangueirinha, Apr 1993, Nupélia. MHNCI 9061, 1, 148.7 mm SL, rio Iguaçu, Municipality of Lapa, 2546'10”S 49¹6’23”W, 20 Sep 2001, F. X. Wegbecher \& I. A. Rodriguez. NUP 552, 3, 216.0-253.0 mm SL, Cavernoso reservoir, rio Cavernoso, tributary of rio Iguaçu,

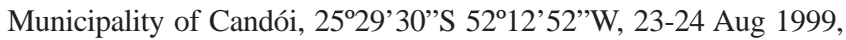
Copel. NUP 596, 2, 67.9-287.5 mm SL, córrego Passo do Aterrado, tributary of rio Jordão, Municipality of Foz do Jordão, $25^{\circ} 45^{\prime}$ 'S 52 $10^{\circ}$ 'W, 17 Nov 1997, Copel. NUP 1592, 3, 232.4-244.2 mm SL, downstream Salto Segredo reservoir, rio Iguaçu, Municipality of Mangueirinha/ Reserva do Iguaçu, 254도 5205’W, 3 Feb 1995, Nupélia. NUP 1627, 2, 196.2-210.3 mm SL, upstream Salto Caxias reservoir, rio Jaracatiá, tributary of Iguaçu, Municipality of Capitão Leônidas Marques/Nova Prata do Iguaçu, 2532'12”S 53²9'11'W, 28 Oct 1999, Nupélia. NUP 2541, 4, 123.6-270.6 mm SL, Foz do Areia reservoir, rio Iguaçu, Municipality of Cruz Machado/Bituruna, 26 $00^{\circ} \mathrm{S} 51^{\circ} 37^{\prime} \mathrm{W}, 27$ Oct 1998, Nupélia. NUP 2991, 9, 135.4-249.9 mm SL, Foz do Areia reservoir, rio Areia, tributary of rio Iguaçu, Municipality of Cruz Machado/ Bituruna, $26^{\circ} 00^{\prime} \mathrm{S} 51^{\circ} 37^{\prime} \mathrm{W}, 14$ Nov 2000, Copel. NUP 2998, 4, 212.8$249.1 \mathrm{~mm}$ SL, Foz do Areia reservoir, rio Areia, tributary of rio Iguaçu,

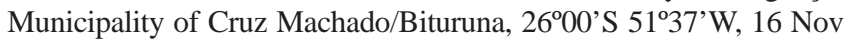
2000, Copel. NUP 4587, 1, 271.0 mm SL, Salto Santiago reservoir, rio Iguaçu, Municipality of Saudade do Iguaçu/Rio Bonito do Iguaçu, 2538'03"S 52³6’03"W, 1 Nov 2004, Gerpel. NUP 4588, 2, 155.5$189.9 \mathrm{~mm}$ SL, Salto Santiago reservoir, rio Iguaçu, Municipality of

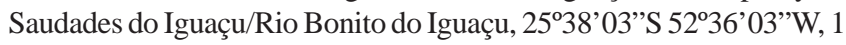
Nov 2004, Gerpel. NUP 5838, 2, 66.3-182.9 mm SL, Jordão reservoir, rio Jordão, tributary of rio Iguaçu, Municipality of Foz do Jordão/ Reserva do Iguaçu, 2545'13”'S 5205'09”'W, 15 Sep 1997, Copel. NUP $5890,1,176.1 \mathrm{~mm}$ SL, Salto Segredo reservoir, rio Iguaçu, tributary of rio Iguaçu, Municipality of Mangueirinha/Reserva do Iguaçu, $25^{\circ} 45^{\prime} \mathrm{S}$ 5205’W, Nov 2001, Nupélia. NUP 5891, 158.6 mm SL, Salto Segredo reservoir, rio Iguaçu, Municipality of Mangueirinha/Reserva do Iguaçu, 254'ㅇ 52 $05^{\circ}$ 'W, Jun 2002, Nupélia. NUP 5915, 2, 130.2-147.9 mm SL, Foz do Areia reservoir, rio Areia, tributary of rio Iguaçu, Municipality of Pinhão/Bituruna, $26^{\circ} 00^{\prime}$ 'S $51^{\circ} 37^{\prime} \mathrm{W}, 6$ Oct 1999, Nupélia. NUP 5916, 1, 205.8 mm SL, Foz do Areia reservoir, rio Areia, tributary of rio Iguaçu, Municipality of Pinhão/Bituruna, $26^{\circ} 00^{\prime}$ 'S 51³7’W, 24 May 2000, Nupélia.

Diagnosis. Hypostomus commersoni can be distinguished from the species of the $H$. cochliodon group of species, except $H$. hemicochliodon, by having bifid not spoonshaped teeth and with the lateral cups not fused to the mesial one (vs. spoon-shaped teeth with lateral cups usually fused to the mesial one). It is also distinguished from the remaining congeners, except $H$. carinatus, $H$. hemicochliodon, $H$. hoplonites, $H$. plecostomus, $H$. tapijara, and $H$. watwata by having strong keels along each of the lateral series of plates (vs. lacking strong keels). From $H$. carinatus, $H$. hemicochliodon, $H$. hoplonites and $H$. watwata it is distinguished by having a higher number of teeth on each dentary, 23-53 (vs. 13-18 in H. carinatus, 
7-23 in H. hemicochliodon, 12-21 in H. hoplonites, and 1929 in $H$. watwata). It is further distinguished from $H$. watwata by having the upper and the lower unbranched caudal-fin ray length almost to just equaling predorsal distance length ( $v s$. clearly surpassing this distance in adult individuals; e.g. In MNHN A.8919, syntype of $H$. watwata). From $H$. tapijara it is distinguished by cleithral width 26.635.7\% in SL (vs. 23.5-27.2), by caudal peduncle depth 8.9$10.4 \%$ in SL (vs. 8.0-9.0), and by dorsal-spine length 32.6$45.0 \%$ in SL (vs. 27.6-34.3).
Description. Dorsal profile of head slightly curved from tip of snout to anterior orbit; supraoccipital profile high and curved to the dorsal-fin insertion. Head elevated and slightly compressed, totally covered by dermal bones with dense covering of odontodes. A conspicuous keel on posterior region of pterotic-supracleithrum behind orbit, followed by continuous keel of odontodes along each lateral series of plates to caudal peduncle; two inconspicuous and divergent keels from median region of supraoccipital; followed by dorsal series of plates along caudal peduncle, giving to upper caudal peduncle a

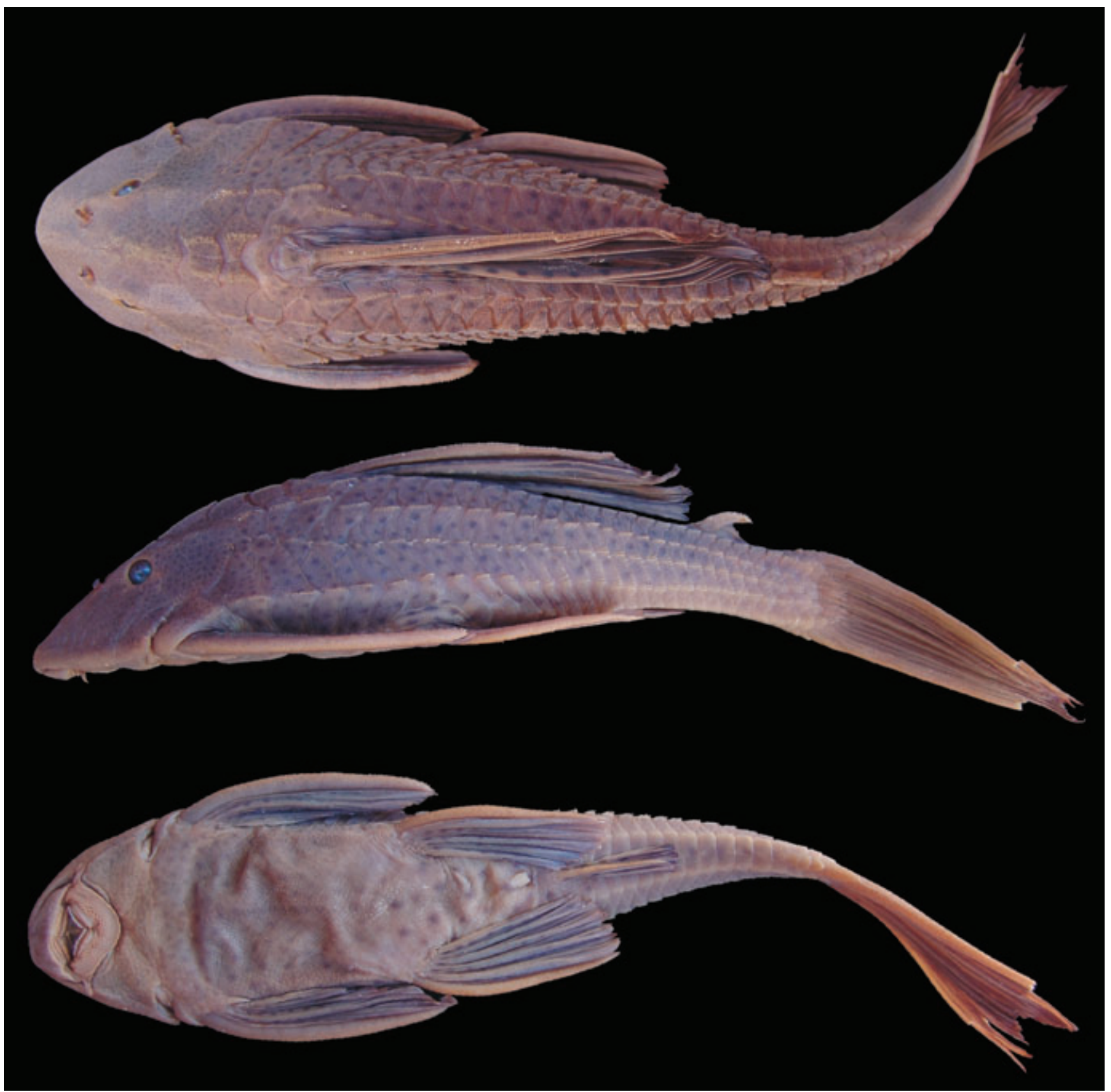

Fig. 2. Hypostomus commersoni, NUP 552, 216.0 mm SL, Cavernoso reservoir, rio Cavernoso, tributary of rio Iguaçu, Municipality of Candói, Paraná, Brazil. 
quadrangular aspect. Snout narrow and compressed, covered by irregular series of small plates. Mesethmoid forming inconspicuous bulge from snout tip to upper region of orbit. Orbit elevated, almost lateral; orbit diameter 11.4-14.3\% in head length. Posterior region of head between supraoccipital and dorsal fin formed by two pair of large plates followed by an unpaired nuchal plate enclosing the first dorsal-fin spinelet. Supraoccipital and pterotic-supracleithrum densely covered with odontodes; larger odontode rows on keels of pteroticsupracleithrum just behind orbit on each side. Dorsal profile of trunk arched at dorsal-fin insertion, slightly declining to caudal fin. Adipose-fin spine short, joined to dorsal caudal peduncle by a slim membrane. Dorsal, mid-dorsal, middle, and mid-ventral series of plates in bent plates forming a keel of hypertrophied odontodes from posterior region of scapular bridge to caudal fin; ventral series of plates moderately angled from posterior region of pelvic fin to lower trunk, giving to caudal peduncle a rectangular aspect. Maximum width slightly decreasing from scapular bridge to caudal fin in dorsal view. Dorsal fin II,7; its origin slightly anterior to vertical through pelvic-fin insertion; elongate, surpassing the adipose-fin spine when adpressed; its distal margin convex. Pectoral fin I,6; elongate, surpassing the pelvic-fin insertion; first ray with large odontodes at upper distal region; its distal margin almost straight. Pelvic fin i,5; surpassing half of anal-fin first ray; its distal border slightly convex. Anal fin, i,5; distal border slightly rounded. Caudal fin i,14,i; slightly concave, lower unbranched ray longer than upper.

Body covered by five longitudinal series of large plates, four of them forming conspicuous keels along whole body and with pungent odontodes on median region of each keel. Rostral margin of snout aciculate. Tip of snout covered by irregularly dispersed platelets and with odontodes extending to upper limits of supraoccipital and posterior pteroticsupracleithrum. Scapular bridge totally covered by small plates with odontodes covering practically whole abdomen; only a small naked area in front of each pelvic-fin insertion; two pair of small plates between anal-fin base and anus. Twenty eight plates in lateral line. Lips with dense papillae; labial barbel elongate and free from the labial border; $23-48$ teeth on premaxilla and 24- 53 on dentary; teeth slender and long with internal cusps larger than external ones.

Color pattern. Ground color of head and trunk reddish dark brown, irregularly black spotted with small spots on head and larger and more spaced spots on dorsum. All fins dark brown and interradial membranes hyaline and irregularly black spotted with small spots; unbranched rays dark brown. Abdominal region light brown, usually without spots but some species exhibit dark spots.

Distribution. Known from Paraná-Paraguay basin, rio Iguaçu, rio Uruguay and coastal rivers from south Brazil. In the rio Iguaçu basin $H$. commersoni is found mainly in the main channel of the rio Iguaçu, where it was frequently captured in the several reservoirs from the rio Iguaçu as Foz do Areia, Jordão, Salto Caxias, Salto Santiago and Segredo reservoirs.
Hypostomus commersoni was also captured in some direct tributaries of the rio Iguaçu as rios Cavernoso, Jaracatiá, and Jordão as well as, in a tributary of rio Jordão the córrego Passo do Aterrado.

\section{Hypostomus derbyi (Haseman, 1911) Figs. 3, 4}

Plecostomus derbyi Haseman, 1911:384, pl.79 (type locality: Porto União da Victoria, currently União da Vitória, rio Iguaçu, Paraná, Brasil); Gosline, 1945:78 (ref.); Fowler, 1954:180 (rio Iguaçu, rio Paraná); Fowler, 1954: 180 (rio Iguaçu, rio Paraná).

Hypostomus derbyi: Isbrucker, 1980:28; Gomez et al., 1990:139 (description); López \& Miquelarena, 1991:27 (redescription); Severi \& Cordeiro, 1994:85 (rio Iguaçu); Garavello et al., 1997:78 (rio Iguaçu); Zawadzki et al., 1999:96 (allozymes and morphometrics); Zawadzki et al., 2001:914 (isozymes); Weber, 2003:357 (ref.); Ingenito et al., 2004:26 (list of species); Baungartner et al., 2006:3 (Salto Osório reservoir, rio Iguaçu; check list); Bifi et al., 2006:205 (rio dos Padres; list of species); Carvalho \& Bockmann, 2007:92 (rio Iguaçu).

Material examined. All from Brazil. Paraná State. FMNH 54246, 1, 90.5 mm SL, holotype, Porto União da Victoria, currently Municipality of União da Vitória, rio Iguaçu, 27 Dec 1909, J. D. Haseman. LISDEBE 2653, 15, 83.0-275.0 mm SL, rio Iguaçu, Salto Segredo reservoir, Municipality of Mangueirinha, Nupélia. LISDEBE 2654, 1, $80.0 \mathrm{~mm}$ SL, rio Irai, tributary of rio Iguaçu, near the Encanamento road, Municipality of São José dos Pinhais, J. C. Garavello \& Lisdebe. LISDEBE 2655, 3, 144.0-166.0 mm SL, rio Iguaçu, Municipality of União da Vitória, J. C. Garavello \& Surehma. MHNCI 1255-1259, 5, 70.2-189.0 mm SL, rio Atuba, tributary of rio Iguaçu, Municipality of Curitiba/Pinhais, 2525'40”S 49¹6’23”W, Nov 1965, R. B. Lange \& Z. Alexandre. MHNCI 1260-1268, 9, 52.8$98.0 \mathrm{~mm}$ SL, rio Atuba, tributary of rio Iguaçu, Municipality of Curitiba/Pinhais, 25²5’40”S 49¹6’23’W, Nov 1965, R. B. Lange. MHNCI 1270, 1, 202.2.0 mm SL, rio Atuba, tributary of rio Iguaçu, Municipality of Curitiba/Pinhais, 2525'40”'S 49¹6'23’'W, Nov 1964, W. Esper \& M. H. Nogueira. MHNCI 1447-1450, 4, 147.0-186.0 mm SL, rio Iguaçu, Municipality of Porto Amazonas, 25³2'40”S 4953'25”W, Dec 1976, R. Lange. MHNCI 1451-1457, 11, 49.4202.2 mm SL, rio Iguaçu, Porto Amazonas, Municipality of Porto Amazonas, 25³2’40”'S 4953’25’'W, Dec 1976, R. Lange. MHNCI 5952, 1, 155.3 mm SL, Salto Osório reservoir, rio Iguaçu, Municipality of Quedas do Iguaçu, 1 Jul 1989, W. Severi et al. MHNCI 6013, 1, 143.7 mm SL, Salto Osório reservoir, rio Iguaçu, Municipality of Quedas do Iguaçu, 25²6'58”'S 5254'29”W, Aug 1991, M. Cordeiro et al. MHNCI 6022, 2, 143.7-156.3 mm SL, Salto Osório reservoir, rio Iguaçu, Municipality of Quedas do Iguaçu, 25²6’58”S 5254'29”W, Aug 1991, M. Cordeiro et al. MHNCI 6025, 6, 158.5176.7 mm SL, Salto Osório reservoir, rio Iguaçu, Municipality of Quedas do Iguaçu, 25²6'58”'S 5254'29”W, Aug 1991, M. Cordeiro et al. MHNCI 7086, 5, 150.9-224.3 mm SL, rio Guarani, tributary of rio Iguaçu, Municipality of Três Barras do Paraná, 25²5'08”S 53¹0’50”W, Feb 1993, E. T. Grando et al. MHNCI 7089, 7, 164.9$223.5 \mathrm{~mm}$ SL, rio Guarani, tributary of rio Iguaçu, Municipality of Três Barras do Paraná, 25²5’08”S 53¹0’50”W, Feb 1993, E. T. 
Grando. MHNCI 7094, 9, 175.2-200.2 mm SL, rio Guarani, Municipality of Três Barras do Paraná, 25²5’08”'S 53¹0’50”W, 24 Feb 1993, E. T. Grando et al. MHNCI 7113, 4, 202.5-235.2 mm SL, rio Guarani, tributary of rio Iguaçu, Municipality of Três Barras do Paraná, 25²5’08”'S 53¹0’50’W, Feb 1993, E. T. Grando. MHNCI 7114, 3, 229.0-250.5 mm SL, rio Guarani, tributary of rio Iguaçu, Municipality of Três Barras do Paraná, 25²5’08”S 53¹0’50”W, Feb 1993, E. T. Grando. MHNCI 7129, 19, 268.5-296.3 mm SL, rio Guarani, tributary of rio Iguaçu, Municipality of Três Barras do Paraná, 25²5’08”S 53¹0’50”W, Feb 1993, E. T. Grando. MHNCI 7174, 1, 304.0 mm SL, rio Iguaçu, Municipality of Nova Prata do Iguaçu, 5320'48”S 25³7'57’W, Mar 1993, E. T. Grando. MHNCI 7463 , 1, damaged, mouth of rio da Divisa, Municipality of Guarapuava, 252ㄱ'S 51 ${ }^{\circ} 27^{\prime}$ W, W. B. Wosiacki \& E. T. Grando. MHNCI 7559, 1, 136.8 mm SL, mouth of córrego da Divisa, Municipality of Pinhão, 2541'44”S 51'39'34'W, W. B. Wosiacki \& P. R. A. Pagliosa. MHNCI 7570, 4, 198.0-288.5 mm SL, rio Iguaçu, Municipality of Pinhão, 10 Nov 1991, W. B. Wosiacki \& E. T. Grando. MNRJ 17752, 9, 84.7280,0 mm SL, rio Iguaçu, Municipality of Porto União, 21-25 Apr
1944, G. S. Myers \& A. L. Carvalho. NUP 151, 2, 186.9-207.4 mm SL, mouth of rio Chopim, Municipality of Cruzeiro do Iguaçu/São Jorge do Oeste, 25³4'28”S 4304'24”W, 5 Aug 1999, Copel. NUP 555, 1, 130.4 mm SL, Cavernoso reservoir, rio Cavernoso, Municipality of Virmond/Laranjerias do Sul, 23-24 Aug 1999, Copel. NUP 585, 5, 184.6-268.0 mm SL, Jordão reservoir, rio Jordão, Municipality of Foz do Jordão/Reserva do Iguaçu, 2545’13”S 5205’09’W, 14 Oct 1995, Copel. NUP 586, 2, 234.0-240.0 mm SL, Jordão reservoir, rio Jordão, Municipality of Foz do Jordão/Reserva do Iguaçu, 2545'13”'S 5205’09”W, 14 Oct 1995, Copel. NUP 587, 8, 149.0-207.3 mm SL, Jordão reservoir, rio Jordão, Municipality of Foz do Jordão/Reserva do Iguaçu, 2545'13”'S 5205'09”W, 14 Oct 1995, Copel. NUP 677, 2, 228.3-230.6 mm SL, Salto Caxias reservoir, rio Iguaçu, Municipality of Capitão de Leônidas Marques/Nova Prata do Iguaçu, 25³2’12”S 53²9’11”W, 13 Aug 1997, Nupélia. NUP 679, 5, 274.0-339.0 mm SL, Salto Caxias reservoir, rio Iguaçu, Municipality of Capitão de Leônidas Marques/Nova Prata do Iguaçu, 2532’12”S 53²9’11”W, 13 Aug 1997, Nupélia. NUP 715, 5, 47.9$58.0 \mathrm{~mm}$ SL, Salto Caxias reservoir, rio Iguaçu, Municipality of Capitão
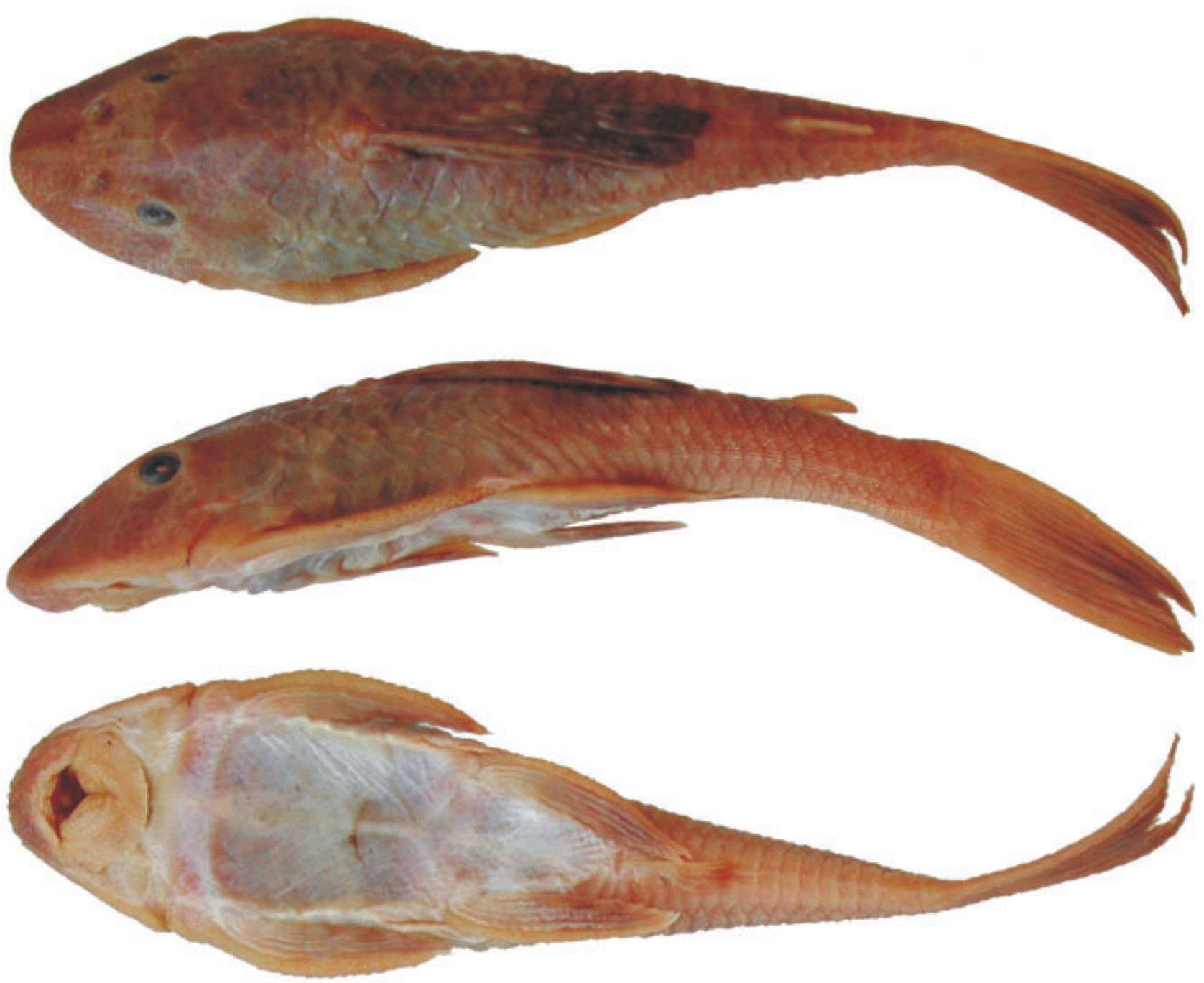

Fig. 3. Holotype of Hypostomus derbyi, FMNH 54246, 90.5 mm SL, Porto União da Victoria, currently Municipality of União da Vitória, rio Iguaçu, Paraná, Brazil. 
de Leônidas Marques/Nova Prata do Iguaçu, 25³2’12”S 53²9’11”W, 13 Aug 1995, Nupélia. NUP 1607, 1, 217.3 mm SL, Salto Segredo reservoir, rio Iguaçu, Municipality of Mangueirinha/Reserva do Iguaçu, 25³0’S 53²5’W, 6 Nov 1995, Nupélia. NUP 1624, 5, 132.1-237.1 mm SL, Salto Caxias reservoir, rio Iguaçu, Municipality of Capitão de Leônidas Marques/Nova Prata do Iguaçu, 2532'12”S 53²9'11”W, 23 Oct 1999, Nupélia. NUP 1791, 7, 126.8-228.1 mm SL, rio Chopim, near its foz at Caxias reservoir, Municipality of Cruzeiro do Iguaçu/ Nova Prata do Iguaçu, 25³4’27”S 5305’49”W, 20 Jan 1999, Nupélia. NUP 1828, 7, 184.0-224.0 mm SL, Salto Caxias reservoir, rio Iguaçu, Municipality of Capitão de Leônidas Marques/Nova Prata do Iguaçu, 25³2’12”S 53²9’11”W. Nupélia. NUP 2541, 6, 129.8-270.0 mm SL, Foz do Areia reservoir, rio Areia, Municipality of Cruz Machado/ Bituruna, 2600’05"S 51³9’23’W, 27 Oct 1998, Nupélia. NUP 2542,

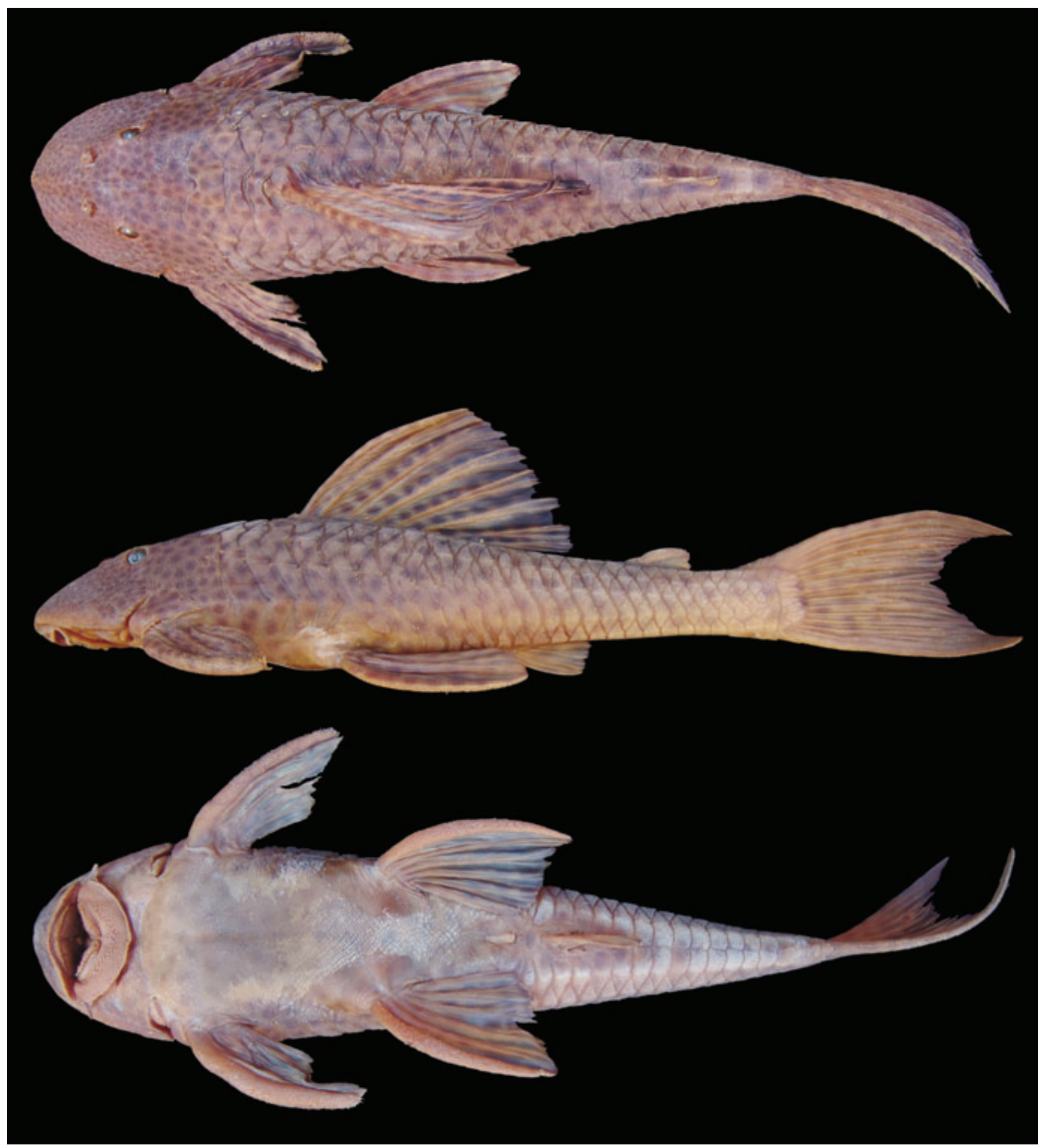

Fig. 4. Hypostomus derbyi, NUP 677, 230.6 mm SL, Salto Caxias reservoir, rio Iguaçu, Municipality of Capitão de Leônidas Marques/Nova Prata do Iguaçu, Paraná, Brazil. 
2, 187.7-192.1 mm SL, Foz do Areia reservoir, rio Areia, Municipality of Cruz Machado/Bituruna, 2600’05”S 51³9’23”W, 13 Nov 2000, Nupélia. NUP 2543, 1, 283.1 mm SL, córrego Passo do Aterrado, tributary of rio Jordão, Municipality of Foz do Jordão, 2545'S $52^{\circ} 10^{\prime} \mathrm{W}, 14$ Oct 1995, Copel. NUP 3684, 5, 98.2-290.4 mm SL, rio Jordão (upstream Santa Clara waterfall), Municipality of Foz do

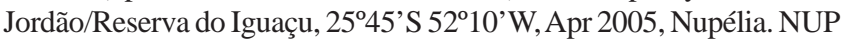
4134, 44, 41.3-156.3 mm SL, rio dos Padres, Municipality of Saudades do Iguaçu, 25³9'34”'S 52`38'08'’, 14 Oct 2004, Gerpel. NUP 4304, 19, 12.3-221.8 mm SL, rio Pinhãozinho, tributary of rio Pinhão, rio Jordão basin, 25³4'23”S 51²7’30”W, 12 Feb 2004, C. H. Zawadzki \& W. J. da Graça. NUP 4305, 4, 137.6.1-225.2 mm SL, rio Cascavel, rio Jordão basin, Municipality of Guarapuava, 25²5'56”'S 5130'20”'W, 5 Apr 2004, L. L. Wolff. NUP 5400, 7, 165.9-258.2 mm SL, Salto Caxias reservoir, rio Iguaçu, Municipality of Capitão Leônidas Marques/Nova Prata do Iguaçu, 254ㄴ 'S 52¹0’W, 25 Jan 2000, Nupélia. NUP 5417, 1, 185.2 mm SL, Foz do Areia reservoir, rio Areia, Municipality of Cruz Machado/Bituruna, 2600’05”S 51³9’23”'W, 1 Nov 1994, Nupélia. NUP 5418, 1, 184.2 mm SL, Foz do Areia reservoir, rio Areia, Municipality of Pinhão/ Bituruna, 2600'S 51³7’W, Jul 2001, Nupélia. NUP 5427, 1, 148.3 mm SL, Jordão reservoir, rio Jordão, Municipality of Foz do Jordão/ Reserva do Iguaçu, 2545’13”S 5205’09”W, Jul 1997, Copel. NUP 5430, 1, 166.2 mm SL, Jordão reservoir, rio Jordão, Municipality of Foz do Jordão/Reserva do Iguaçu, 2545'13”S 5205’09”W, 26 Nov 1996, Nupélia. NUP 5919, 1, 229.3 mm SL, Salto Caxias reservoir, rio Iguaçu, Municipality of Capitão Leônidas Marques/Nova Prata do Iguaçu, 2331'45”S 5329'12”W, 4 Aug 2000, Nupélia. NUP 5920, 3, 186.4-205.7 mm SL, Salto Caxias reservoir, rio Iguaçu, Municipality of Capitão Leônidas Marques/Nova Prata do Iguaçu, 2331'45”S 53²9’12”W, 26 Jan 1999, Nupélia. NUP 5930, 2, 103.9-107.1mm SL, Jordão reservoir, rio Jordão, Municipality of Foz do Jordão/ Reserva do Iguaçu, 2545’13”S 5205’09”W, 21 Mar 1996, Nupélia. NUP 5959, 3, 176.0-224.0 mm SL, rio Iguaçu, Municipality of Lapa, 254’34’S 50¹1'57’W, 16 May 2002, L. F. Duboc \& L. Ingenito. NUP 6810, 2, 236.0-237.0 mm SL, Salto Caxias reservoir, rio Iguaçu, Municipality of Capitão Leônidas Marques, 2331'45”S 5329'12”W, 2 Jan 2006, Copel. NUP 8735, 1, 23.6 mm SL, rio Aurora, tributary of rio das Antas, Municipality of Santo Antônio do Sudoeste, 2602'S 54²4’'W, 4 Jan 2009, W. J. da Graça. NUP 9288, 7, 160.5-206.1 mm SL, córrego Flor da Cunha, tributary rio Iguaçu, Municipality of Três Barras do Paraná, 2528’35”S 53¹1’03”W, 8 Feb 1997, Nupélia. NUP 10386, 6, 68.7-117.6 mm SL, rio dos Padres, tributary rio Iguaçu, Municipality of Saudade do Iguaçu, 2539'35”S 52 38'03'”, 16 jan 2005, Gerpel. Santa Catarina State. LISDEBE 2656, 9, 121.0-153.0 mm SL, rio Timbó, tributary of rio Iguaçu, at Colônia São Pedro, Municipality of Porto União, 26⒉'13”S 50 49'59”W, 20-21 Nov 1986, J. C. Garavello \& Lisdebe.

Diagnosis. Hypostomus derbyi can be distinguished from the species of the $H$. cochliodon group, except $H$. hemicochliodon, by having bifid non spoon-shaped teeth and with the lateral cups not fused to the mesial one (vs. spoon-shaped teeth with lateral cups usually fused to the mesial one). From $H$. alatus, $H$. albopunctatus, $H$. chrysostiktos, $H$. faveolus, $H$. francisci, $H$. lexi, $H$. luteus, $H$. luteofrenatus, $H$. margaritifer, $H$. microstomus, $H$. multidens, $H$. regani, $H$. roseopunctatus, $H$. scaphiceps, $H$. strigaticeps, $H$. tietensis, and $H$. variipictus it is distinguished by having dark spots over body and fins (vs. pale spots). It is distinguished from the remaining congeners, except $H$. agna, $H$. brevicauda, H. brevis, H. garmani, H. goyazensis, H. heraldoi,
H. hermanni, H. iheringii, H. johnii, H. lima, H. luetkeni, $H$. macrops, $H$. nigromaculatus, $H$. nigropunctatus, $H$. ternetzi, $H$. topavae, and $H$. wuchereri, by the absence of keels on pteroticsupracleitrhum, pre-dorsal plates and on lateral series of plates (vs. having moderate to developed keels on pteroticsupracleitrhum, pre-dorsal plates, and lateral series of plates). From $H$. agna, $H$. brevicauda, $H$. heraldoi, $H$. hermanni, $H$. garmani, $H$. johnii, $H$. luetkeni, $H$. nigromaculatus, $H$. vermicularis, and $H$. wuchereri by having deeper body and a pair of parallel moderate keels on pre-dorsal plates (vs. depressed body without keels on pre-dorsal plates). From $H$. brevis, $H$. goyazensis, $H$. johnii, $H$. iheringii, $H$. lima, $H$. ternetzi, and $H$. topavae by having abdomen completely plated (vs. abdomen naked in $H$. brevis and partially plated in $H$. goyazensis, H. johnii, $H$. iheringii, H. lima, H. macrops, $H$. ternetzi, and H. topavae). From $H$. nigropunctatus by middle-sized and moderate-set dark spots (approximately equal to eye diameter length) on dorsal region of head, trunk, and fins (vs. small-sized and close-set dark spots, that is, equal to smaller than eye pupil on dorsal region of head, trunk, and fins); and by having usually one pre-dorsal plate bordering supraoccipital (vs. three plates).

Description. Dorsal profile of head almost straight from tip of snout to supraoccipital; supraoccipital concave from this point through pre-dorsal plates to origin of dorsal-fin insertion. Head elevated and compressed, totally covered by plates with dense covering of odontodes. A slender keel on upper pteroticsupracleithrum just behind orbit, conspicuous on first three posterior plates; slightly decreasing in size to caudal peduncle on each side. Snout narrow and compressed, covered by irregular series of small plates. Mesethmoid forming an inconspicuous keel from snout tip to upper region of orbit. Upper orbital margin elevated, laterally positioned; orbital diameter 11.9-15.0\% in head length. Posterior region of head between supraoccipital and dorsal fin having two pair of large plates and a narrow unpaired plate near the dorsal-fin platelet. Supraoccipital and pterotic-supracleithrum densely covered by odontodes irregularly inserted not forming salient series or keels on posterior region of head. Dorsal profile of trunk almost straight from dorsal-fin insertion to caudal fin. Adipose fin large. Maximum body width at posterior region of scapular bridge gradually decreasing to caudal fin. Dorsal fin II,7; its origin at two vertical plates before pelvic-fin insertion; not reaching adipose-fin spine; its distal margin convex. Pectoral fin I,6 rays; unbranched ray elongate, with strong odontodes on distal region; reaching or surpassing the pelvic-fin insertion; its distal border almost straight. Pelvic fin i,5 rays; unbranched pelvicfin rays reaching or surpassing the anal-fin insertion; its distal margin straight to slightly convex. Anal fin, i,5; distal border slightly rounded. Caudal fin i,14,i rays, deeply notched; lower lobe longer than upper.

Body covered by five lateral series of plates. Dorsal, middorsal, median and ventral series of plates not bearing conspicuous keels. Mid-ventral series of plates moderately keeled on lateral abdomen through six plates from scapular bridge. Rostral margin of snout aciculate and with dense series 
of odontodes; lips deeply forked at insertion. Snout tip formed by irregular series of plates covering from snout to anterior orbit, to limits of upper supraoccipital and lateral pteroticsupracleithrum. Scapular bridge totally covered by gross skin and small plates with odontodes, covering the whole abdomen; only a small naked region on insertion of pelvic fins and in the region in front of anus. Two pair of narrow plates not meeting at median region between anal-fin insertion and anus and with a naked area between them. Twenty eight to twenty nine plates in the lateral line. Lips and oral region semicircular, with dense papillae; labial barbel elongate and joined to labial border by a gross membrane. Premaxilla with 21 to 42 and dentary with 23 to 43 teeth of moderate length, with two cusps nearly equal in size.

Color pattern. Ground color of head and trunk brown uniform; dorsal region of head, trunk, and fins densely black spotted with small spots on head and larger spots on flanks and whole fins. Interradial membranes hyaline and the black spots forming transversal lines through fins, mainly on dorsal fin. Branched rays of whole fins dark brown uniform. Abdominal region light brown, irregularly black spotted or vermiculated on whole abdomen and ventral caudal peduncle. Unbranched ray of pectoral, pelvic, anal, and caudal fins light brown in ventral regions but black spotted on upper regions.

Distribution. Known from rio Iguaçu basin, Paraná and Santa Catarina States, Brazil. Hypostomus derbyi is the more widespread and abundant species of Hypostomus within the basin. Besides being abundant in the main channel of the rio Iguaçu it is also common in the small to medium streams of the basin. In some streams as the rio das Antas, rio das Pedras, rio dos Padres, and rio Pinhaozinho, among others, it was the sole Hypostomus captured.

\section{Hypostomus myersi (Gosline, 1947) Figs. 5, 6}

Plecostomus myersi Gosline, 1947:116, pl. 5; figs. 9-10 (Type locality: Porto União da Vitória, actual Municipality of União da Vitória, rio Iguaçu, Paraná, Brazil).

Hypostomus myersi: Isbrucker, 1980:28 (new comb.); Gomes et al., 1990:139 (description and biological data); López \& Miquelarena, 1991:35 (redescription); Severi \& Cordeiro, 1994:87 (rio Iguaçu, Porto União); Garavello et al., 1997:79 (rio Iguaçu); Zawadzki et al., 1999:96 (allozymes and morphometrics); Zawadzki et al., 2001:914 (isozymes); Weber, 2003:360 (ref.); Baungartner et al., 2006:3 (Salto Osório reservoir, rio Iguaçu; check list); Carvalho \& Bockmann, 2007:93 (rio Iguaçu).

Material examined. All from Brazil. Paraná State. MNRJ 4251, holotype, 174.0 mm SL, Porto União, rio Iguaçu, 21-25 Apr 1944, G. S. Myers \& A. L. Carvalho. MNRJ 4252, paratypes, 2, 124.5-200.0 $\mathrm{mm}$ SL, same locality and collectors as holotype. LISDEBE 2657, 14, 116.0-164.0 mm SL, Salto Segredo reservoir, rio Iguaçu, Municipality of Mangueirinha, 2548’S 5209’W, Apr 1993, Nupélia.
LISDEBE 2658, 10, 117.0-215.0 mm SL, rio Iguaçu, Municipality of Porto Lupion, 1979-1980, J. C. Garavello \& Surehma. LISDEBE 2659, 5, 116.0-192.0 mm SL, downstream Salto Osório reservoir, rio Iguaçu, Municipality of Quedas do Iguaçu, 25³2'S 5301'W, 19 Jan 1990, J. C. Garavello et al. LISDEBE 2660, 2, 126.0-157.0 mm SL, rio Iguaçu, Municipality of União da Vitória, 26¹3'S 5306’W, 6 March 1979, J. C. Garavello \& Surehma. MHNCI 6049, 2, 123.3$146.1 \mathrm{~mm}$ SL, Salto Osório reservoir, Municipality of Quedas do Iguaçu, 25³3'S 5256’ W, 20 Aug 1991, Hicson et al. MHNCI 7082, 13, 77.2-182.0 mm SL, rio Guarani, Municipality of Três Barras, 2525’08”S 53¹0’50”W, Feb 1993, E. T. Grando et al. MHNCI 7093, 12, 119.0-182.8 mm SL, rio Guarani, Municipality of Três Barras, 25²5’08”S 53¹0’50”W, Feb 1993, E. T. Grando et al. MHNCI 7104, 14, 125.1-185.0 mm SL, rio Guarani, Municipality of Três Barras, 25²5’08”S 53¹0’50”W, Feb 1993, E. T. Grando et al. MHNCI 7105, 11, 115.7-172.9 mm SL, rio Guarani, Municipality of Três Barras, 25²5’08”S 53¹0’50”W, Feb 1993, E. T. Grando et al. MHNCI 7107, 1, $87.1 \mathrm{~mm}$ SL, rio Guarani, Municipality of Três Barras, 25²5’08”S 53¹0’50”W, Feb 1993, E. T. Grando et al. MHNCI 7108, 2, 141.2-144.1 mm SL, rio Guarani, Municipality of Três Barras, 25²5’08”S 53¹0’50”W, Feb 1993, E. T. Grando et al. MHNCI 7116, 9, 130.6-175.4 mm SL, rio Guarani, Municipality of Três Barras, 25²5’08”S 53¹0’50”W, Feb 1993, E. T. Grando et al. MHNCI 7133, 5, 173.0-200.0 mm SL, rio Iguaçu, Municipality of Nova Prata do Iguaçu, 53²0'48”'S 2537'57”W, Mar 1993, E. T. Grando et al. MHNCI 7140, 2, 198.7-203.8 mm SL, rio Iguaçu, Municipality of Nova Prata do Iguaçu, 5320'48'S 2537'57'W, Mar 1993, E. T. Grando et al. MHNCI 7160, 4, 198.7-203.8 mm SL, rio Cotegipe, Municipality of Nova Prata do Iguaçu, 5320'48”S 2537'57’W, Mar 1993, E. T. Grando et al. MHNCI 7162, 13, 99.3169.2 mm SL, rio Iguaçu, Municipality of Nova Prata do Iguaçu, 5320'48'S 25³7'57'W, Mar 1993, E. T. Grando et al. MHNCI 7163, 9, 157.6-200.0 mm SL, rio Iguaçu, Municipality of Nova Prata do Iguaçu, 53²0'48”S 2537’57’W, Mar 1993, E. T. Grando et al. MHNCI 7164, 13, 99.3-169.2 mm SL, rio Iguaçu, Municipality of Nova Prata do Iguaçu, 53²0'48”'S 2537'57'W, Mar 1993, E. T. Grando et al. MHNCI 7165, 15, 78.3-184.0 mm SL, rio Iguaçu, Municipality of Nova Prata do Iguaçu, 5320'48'S 2537'57'W, Mar 1993, E. T. Grando et al. MHNCI 7427, 1, 23.3 mm SL, mouth of córrego da Divisa, Municipality of Pinhão, 9 Apr 1992, W. B. Wosiacki \& P. R. A. Pagliosa. MHNCI 7480, 3, 67.0-77.0 mm SL, downstream Lutscher reservoir, rio Jordão, Municipality of Pinhão, 24 Oct 1991, W. B. Wosiacki et al. MHNCI 7529, 1, 80.0 mm SL, mouth of córrego Bragança, Municipality of Pinhão, 10 Nov 1991, W. B. Wosiacki \& E. T. Grando. MHNCI 7633, 1, 116.4 mm SL, rio Jordão, upstream Vaca Branca waterfall, Municipality of Pinhão/Guarapuava, 23 Oct 1991, W. B. Wosiacki et al. MHNCI 7650, 1, 87.5 mm SL, rio Jordão, Municipality of Jordão/Guarapuava, 22 Oct 1991, W. B. Wosiacki et al. MHNCI 7732, 5, 76.5-115.2 mm SL, rio Jordão, downstream Lutscher reservoir, Municipality of Jordão/Guarapuava, 24 Oct 1991, W. B. Wosiacki et al. MHNCI 7762, 1, 159.3 mm SL, rio Jordão, downstream Lutscher reservoir, Municipality of Jordão/Guarapuava, 24 Oct 1991, W. B. Wosiacki et al. MHNCI 8161, 1, 143.0 mm SL, Salto Osório reservoir, rio Iguaçu, Municipality of Quedas do Iguaçu, 253'S 5259'W, 13 Feb 1990, W. Severi et al. MHNCI 8348, 1, 185.4 mm SL, Bento Munhoz da Rocha Neto reservoir, rio Iguaçu,

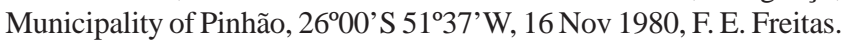
MHNCI 8841, 8, 158.6-190.2 mm SL, mouth of rio Bragança, Municipality of Pinhão, 10 Sep 1992, W. B. Wosiacki. MHNCI 10270, 11, 90.7-153.1 mm SL, rio Cavernoso, Municipality of Pinhão, 2529’02”S 52¹2'58”W, 17 Feb 2004, L. P. Bastos \& D. P. A. Filho. MHNCI 10382, 2, 136.5-155.1 mm SL, rio Andrada, Municipality 


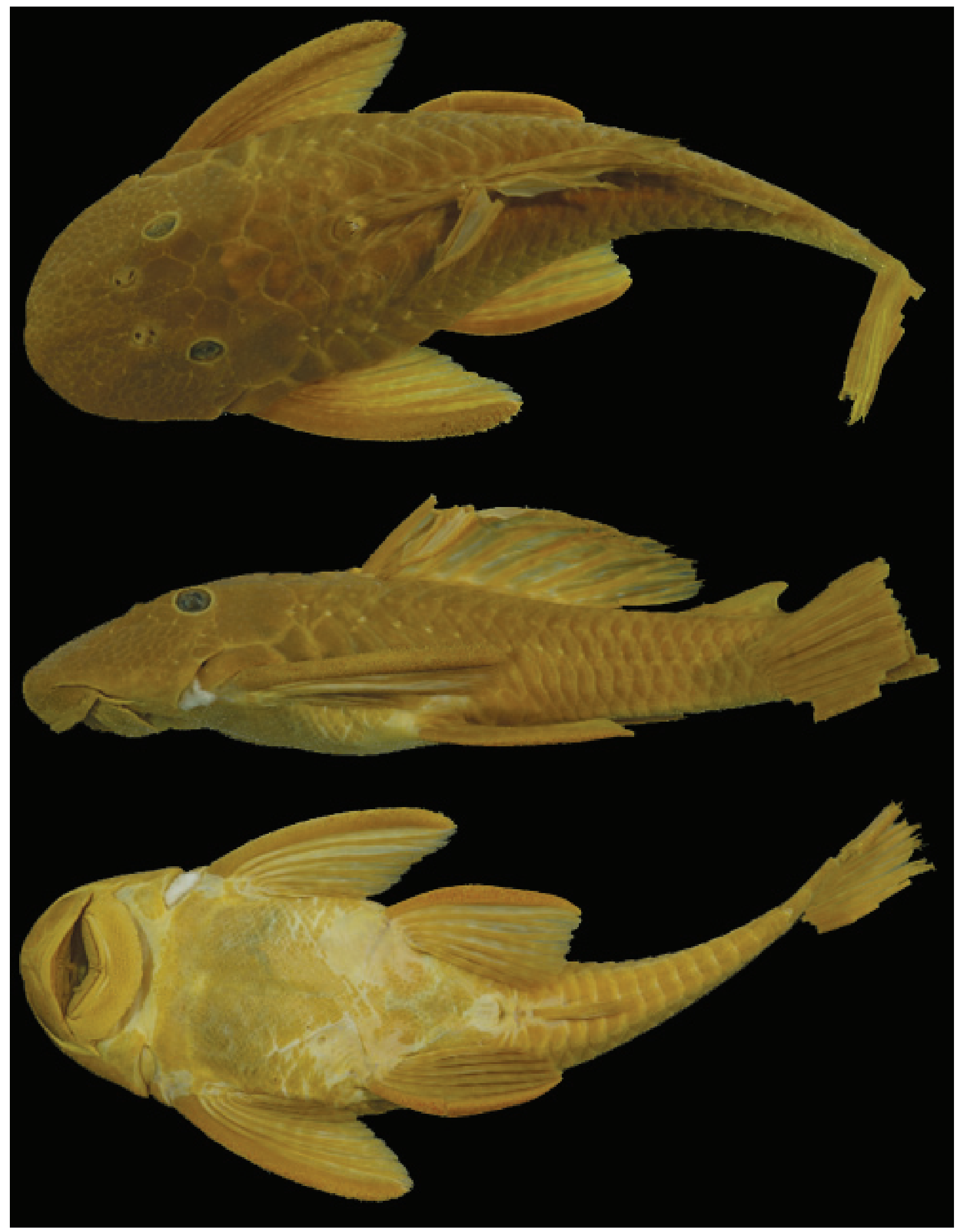

Fig. 5. Holotype of Hypostomus myersi MNRJ 4251, 174.0 mm SL, Porto União, rio Iguaçu, Paraná, Brazil. 


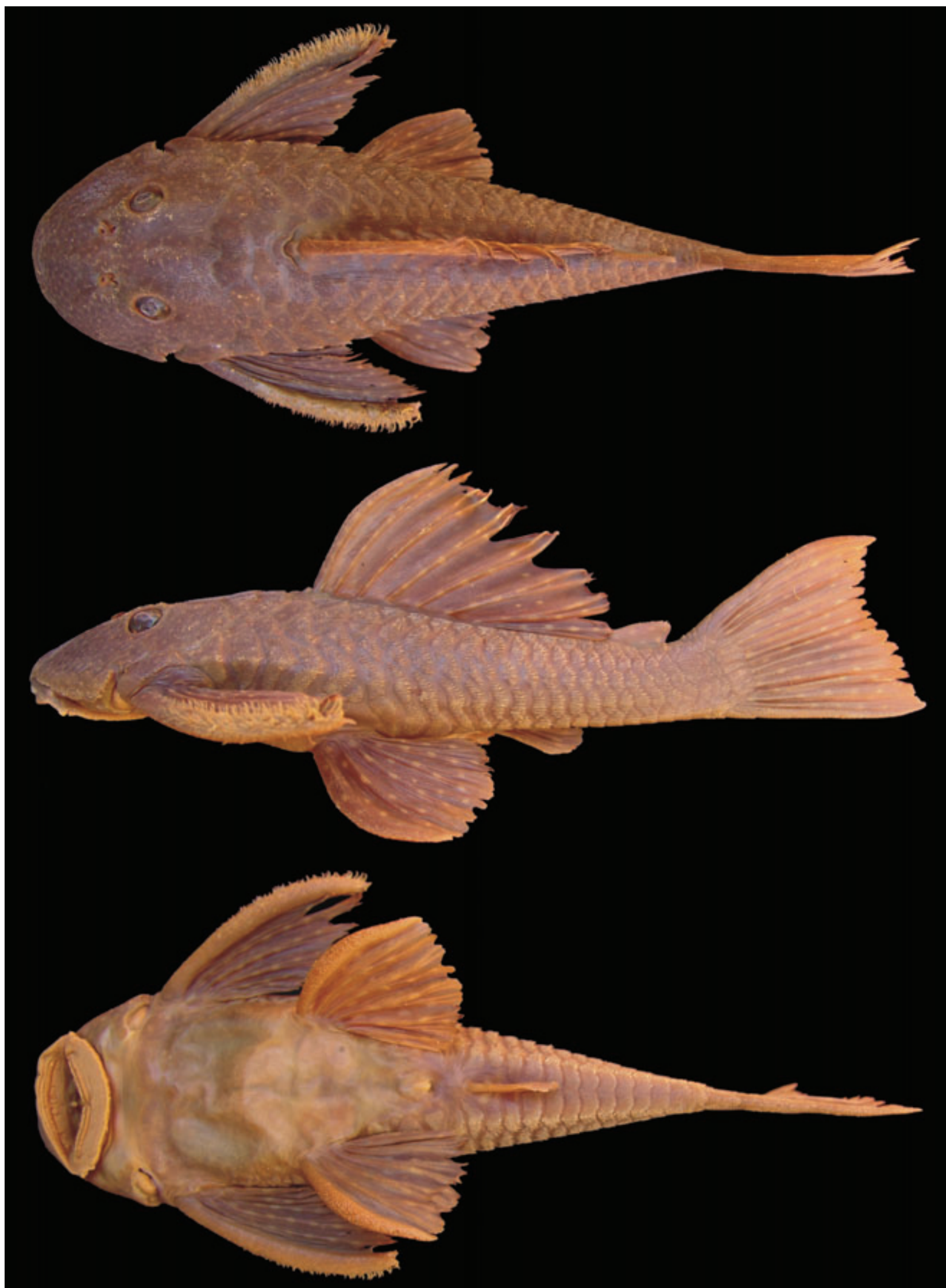

Fig. 6. Hypostomus myersi, NUP 680, 146.2 mm SL, Salto Caxias reservoir, rio Iguaçu, Municipality of Capitão Leônidas Marques/Nova Prata do Iguaçu, Paraná, Brazil. 
of Capitão Leônidas Marques, 25³1’04”S 53³1’33”W, 6 Apr 2004, L. P. Bastos \& D. P. A. Filho. MHNCI 10708, 3, 161.0-187,5 mm SL, rio Iguaçu, Municipality of São Mateus do Sul, 2547'34”S 50¹1'57’W, 12 Oct 2002, L. F. Duboc et al. MHNCI 10716, 1, 180.0 mm SL, rio Iguaçu, Municipality of São Mateus do Sul, 2547’34’S 50¹1'57’W, 12 Oct 2002, L. F. Duboc et al. MHNCI 11739, 1, 167.0 mm SL, rio Guarani, Três Barras do Paraná, 2525’08”'S 53¹0’50”W, 23 Feb 1993, E. T. Grando et al. MHNCI 11744, 1, 151.0 mm SL, Salto Caxias reservoir, 15 Aug 1994, E. T. Grando et al. MHNCI 11746, 3, 109.2-120.0 mm SL, downstream Lutscher reservoir, rio Jordão, tributary of rio Iguaçu, Municipality of Pinhão, 27 Oct 1991, W. B. Wosiacki et al. MHNCI 11754, 1, $125.0 \mathrm{~mm}$ SL, Salto Santiago reservoir, Municipality of Quedas do Iguaçu, 2532'S 52³7'11'W, 30 Jun 1989, W. Severi et al. NUP 150, 1, $252.7 \mathrm{~mm}$ SL, Chopim reservoir, rio Chopim, Municipality of Cruzeiro do Iguaçu, 2534'S 5306'W, 6 Aug 1999, A. A. Agostinho. NUP 557, 1, 131.6 mm SL, Cavernoso reservoir, rio Cavernoso, Municipality of Candói, 2529'30”S 52¹2’52”W, 23-24 Aug 1999, Copel. NUP 680, 3, 93.0-175.4 mm SL, Salto Caxias reservoir, rio Iguaçu, Municipality of Capitão Leônidas Marques/Nova Prata do Iguaçu, 2532'12”S 5329'11”W, 7 Oct 2000, Nupélia. NUP 1625, 8, 86.7-127.3 mm SL, Salto Caxias reservoir, rio Iguaçu, Municipality of Capitão Leônidas Marques/Nova Prata do Iguaçu, 25³2’12”S 53²9’11”'W, 31 Oct 1999, Nupélia. NUP 1675, 15, 71.8-163.1 mm SL, Jordão reservoir, rio Jordão, Municipality of Foz do Jordão/ Reserva do Iguaçu, 2545'13”S 5305’09”W, 28 May 1996, Nupélia. NUP 1789, 19, 69.6-188.6 mm SL, Salto Caxias reservoir, rio Iguaçu, Municipality of Capitão Leônidas Marques/Nova Prata do Iguaçu, 2532'12”S 5329'11’'W, 20 Jan 1999, Nupélia. NUP 1805, 5, 167.5205.4 mm SL, Salto Caxias reservoir, rio Iguaçu, Municipality of Capitão Leônidas Marques/Nova Prata do Iguaçu, 25³2'12”S 53²9’11”W, 20 Jan 1999, Nupélia. NUP 1829, 2, 209.2-245.6 mm SL, Salto Caxias reservoir, rio Iguaçu, Municipality of Capitão Leônidas Marques/Nova Prata do Iguaçu, 2532'12”S 53²9’11”W, 20 Jan 1999, Nupélia. NUP 1835, 5, 154.8-182.9 mm SL, Salto Caxias reservoir, rio Iguaçu, Municipality of Capitão Leônidas Marques/Nova Prata do Iguaçu, 2532'12”S 5329'11’W, 20 Jan 1999, Nupélia. NUP 2959, 5, 115.2-158.0 mm SL, Foz do Areia reservoir, rio Areia, Municipality of Cruz Machado/Bituruna, 2600'S 513'W, 1 Jan 2003, Copel. NUP 3009, 7, 103.3-145.2 mm SL, Salto Segredo reservoir, rio Iguaçu, Municipality of Mangueirinha/Reserva do Iguaçu, 254' S 52 05’W, 17 Jan 2002, Copel. NUP 5748, 1, 139.1 mm SL, Foz do Areia reservoir, rio Areia, Municipality of Cruz Machado/

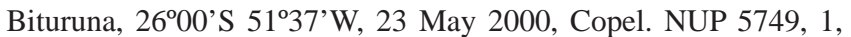
$140.1 \mathrm{~mm}$ SL, Foz do Areia reservoir, rio Areia, Municipality of Cruz

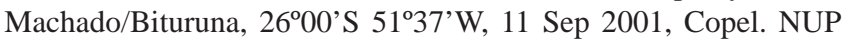
5750, 2, 106.4-134.7 mm SL, Foz do Areia reservoir, rio Areia,

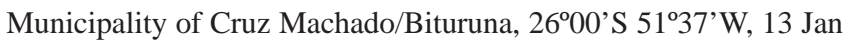
2002, Copel. NUP 5751, 2, 142.2-156.8 mm SL, Foz do Areia reservoir, rio Areia, Municipality of Cruz Machado/Bituruna, 260.'S 51 ${ }^{\circ} 37^{\circ} \mathrm{W}$, 29 Jan 2002, Copel. NUP 5752, 5, 98.2-126.8 mm SL, Foz do Areia reservoir, rio Areia, Municipality of Cruz Machado/Bituruna, 2600'S 51ํㄱㄱ'W, 10 Apr 2002, Copel. NUP 5753, 2, 125.5-178.6 mm SL, Foz do Areia reservoir, rio Areia, Municipality of Cruz Machado/

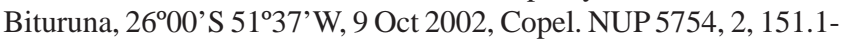
$159.4 \mathrm{~mm}$ SL, Foz do Areia reservoir, rio Areia, Municipality of Cruz Machado/Bituruna, 26으'S $/ 51^{\circ} 37^{\prime}$ W, 1 Apr 2003, Copel. NUP 5755, 1, $142.8 \mathrm{~mm}$ SL, Foz do Areia reservoir, rio Areia, Municipality of Cruz Machado/Bituruna, 2600'S 51 ${ }^{\circ} 37^{\circ} \mathrm{W}, 1$ Jul 2003, Copel. NUP 5892, 8, 22.1-134.9 mm SL, Salto Caxias reservoir, rio Iguaçu, Municipality of Capitão Leônidas Marques/Nova Prata do Iguaçu, 2532’12”S 5329’11”'W, 21 Jan 1999, Nupélia. NUP 5924, 12, 81.5-
161.8 mm SL, Salto Caxias reservoir, rio Iguaçu, Municipality of Capitão Leônidas Marques/Nova Prata do Iguaçu, 25³2'12”S 53²9’11”W, 24 Jan 1999, Nupélia. NUP 5925, 3, 135.7-142.0 mm SL, Salto Caxias reservoir, rio Iguaçu, Municipality of Capitão Leônidas Marques/Nova Prata do Iguaçu, 25³2’12"S 53²9’11”W, 19 Jul 1999, Nupélia. NUP 5932, 2, 108.0-161.3 mm SL, Salto Segredo reservoir, rio Iguaçu, Municipality of Mangueirinha/Reserva do Iguaçu, 254’ S 5205’W, 5 Jun 2001, Copel. NUP 5933, 1, 150.2 mm SL, Salto Segredo reservoir, rio Iguaçu, Municipality of Mangueirinha/ Reserva do Iguaçu, 2545'S 5205’W, Mar 2003, Copel. NUP 5951, 1, 119.1 mm SL, rio Iguaçu, Municipality of Araucária, 25³6’55”S 5307’55”W, 29 Jul 2000, A. A. Agostinho. NUP 5952, 2, 149.5158.5 mm SL, Salto Caxias reservoir, rio Iguaçu, Municipality of Capitão Leônidas Marques/Nova Prata do Iguaçu, 25³2'12”S 5329'11”W, 9 Oct 1997, Nupélia. NUP 5953, 3, 154.1-176.2 mm SL, Salto Caxias reservoir, rio Iguaçu, Municipality of Capitão Leônidas Marques/Nova Prata do Iguaçu, 2532'12”S 53²9'11”W, 30 Apr 1999, Nupélia. NUP 5954, 1, 68.4 mm SL, Salto Caxias reservoir, rio Iguaçu, Municipality of Capitão Leônidas Marques/ Nova Prata do Iguaçu, 2532’12”S 53²9'11’W, 10 Jan 2001, Nupélia. NUP 5955, 2, 114.1-174.8 mm SL, Salto Caxias reservoir, rio Iguaçu, Municipality of Capitão Leônidas Marques/Nova Prata do Iguaçu, 2532'12”S 5329'11”W, 9 Sep 2000, Nupélia. NUP 5958, 3, 94.7$137.3 \mathrm{~mm}$ SL, Salto Segredo reservoir, rio Iguaçu, Municipality of Mangueirinha/Reserva do Iguaçu, 2545'S 5205’W, 22 May 1993, Nupélia. NUP 5960, 3, 106.2-117.3 mm SL, Jordão reservoir, rio Jordão, Municipality of Foz do Jordão/Reserva do Iguaçu, 2545’13”S 5205’09”'W, 11 Dec 1995, Nupélia. NUP 6093, 3, 29.2-200.2 mm SL, Salto Segredo reservoir, rio Iguaçu, Municipality of Mangueirinha/ Reserva do Iguaçu, 2545'S 5205’W, 22 May 1993, Nupélia. NUP 6239, 2, 168.4 mm SL, Salto Osório reservoir, rio Iguaçu, Municipality of Quedas do Iguaçu, 2532’32”S 5301’48”W, 10 Sep 2005, Gerpel. NUP 6244, 3, 125.0-149.0 mm SL, Salto Santiago reservoir, rio Iguaçu, Municipality of Quedas do Iguaçu, 2537'32”S 52³7'13”W, 7 Dec 2004, Gerpel. NUP 6368, 3, 29.4-202.5 mm SL, Salto Segredo reservoir, rio Iguaçu, Municipality of Mangueirinha/Reserva do Iguaçu, 2545'S 5205’W, Mar 1995, Nupélia. NUP 7074, 148.0 mm SL, Foz do Areia reservoir, rio Areia, Municipality of Cruz Machado/Bituruna, 26ํㅇ'S 51 $37^{\circ}$ 'W, 14 Nov 2000, Copel.

Diagnosis. Hypostomus myersi can be distinguished from the species of the $H$. cochliodon group, except $H$. hemicochliodon, by having bifid not spoon-shaped teeth and with the lateral cups not fused to the mesial one (vs. spoon-shaped teeth with lateral cups usually fused to the mesial one). Hypostomus myersi is distinguished from all remaining congeners except $H$. alatus, $H$. albopunctatus, $H$. chrysostiktos, $H$. faveolus, $H$. francisci, $H$. lexi, $H$. luteus, $H$. luteofrenatus, $H$. margaritifer, $H$. microstomus, $H$. multidens, $H$. regani, $H$. roseopunctatus, $H$. strigaticeps, $H$. tietensis, and $H$. variipictus by having pale spots or pale vermiculations over body and fins (vs. dark spots over body and fins). From $H$. microstomus, $H$. margaritifer, $H$. roseopunctatus, $H$. tietensis, and $H$. variipictus by having 64-90 teeth on each mandibular ramus (vs. 9-16 in H. microstomus, 18-32 in $H$. margaritifer and in $H$. variipictus, 6-16 in $H$. roseopunctatus, and 45-54 in $H$. tietensis). From $H$. alatus, $H$. francisci, $H$. luteofrenatus, $H$. luteus, and $H$. regani by having depressed head and eye dorsally placed (vs. compressed head and eye laterally placed). From $H$. meleagris and $H$. strigaticeps by having scapular bridge totally covered by gross skin and with dense 
covering of odontodes on small platelets (vs. scapular bridge usually naked). From $H$. albopunctatus by pelvic-fin unbranched ray smaller than pectoral-fin unbranched ray ( $v$ s. pelvic-fin unbranched ray equal to larger than pectoral-fin unbranched ray). From $H$. chrysostiktos by having seven branched ray on dorsal fin (vs. eight). From $H$. multidens by having asymmetric bicuspid teeth (vs. symmetric).

Description. Dorsal profile of head from tip of snout to dorsalfin insertion slightly concave and elevated at supraoccipital region. Head broad and depressed, totally covered by large dermal bones with fine odontodes; rows of dense odontodes on posterior region of orbit and on median supraoccipital, forming a slightly depression between this bone and orbit. Snout broad and depressed. Mesethmoid forming an inconspicuous bulge from snout tip to upper region of orbit. Orbit narrow, almost dorsal; orbital diameter 14.6-21.7\% in head length. Posterior region of head between supraoccipital and dorsal-fin insertion covered by three unpaired and narrowed pre-dorsal plates with a dense series of odontodes in median region forming a divergent keel from supraoccipital. A small platelet on first dorsal-fin ray. Nares narrow, nearly four times in intranasal distance. Body profile slightly straight from dorsalfin insertion to caudal peduncle. Adipose fin elevated and inserted five plates after dorsal-fin posterior insertion. Caudal peduncle with longitudinal series of odontodes at median region of each plate; upper region of caudal peduncle slightly concave and lower region almost straight. Maximum body width at pectoral-fin insertion, gradually decreasing from this point to base of caudal fin. Unpaired nuchal plate in front of dorsalfin insertion elevated. Dorsal fin II,7; its origin little ahead vertical through pelvic-fin insertion; almost reaching adipose-fin spine when adpressed; its distal border slightly convex. Pectoral fin I,6; unbranched pectoral fin ray elongate, reaching median portion of pelvic fin and covered by numerous large odontodes; its distal border slightly convex. Pelvic fin i,5; not to just reaching anal-fin insertion; its distal border straight to slightly convex. Anal fin, i,5; distal border slightly rounded. Caudal fin i,14,i, slightly notched; lower unbranched ray longer than upper.

Body covered by five series of longitudinal plates; median series with origin at posterior region of scapular bridge and with a salient keel of odontodes decreasing in size on posterior plates of series. Some rows of odontodes running at median region of all plates on first and second dorsal series of plates; becoming inconspicuous on posterior plates of caudal peduncle. Rostral margin of snout in ventral view aciculate. Tip of snout formed by upper lip in part; snout tip with a naked area without odontodes. Irregular series of small bones between upper snout and orbit running to posterior limits of supraoccipital and pterotic-supracleithrum. Scapular bridge totally covered by gross skin and with dense covering of odontodes on small plates. Numerous small plates and platelets in juveniles covering scapular bridge to pelvic-fin insertion and almost whole abdomen. Abdomen almost totally covered by minute plates, with minute odontodes, leaving naked areas at anterior region of pelvic-fin insertion, around anus and in front of anal-fin insertion; region between anal fin and anus covered only by skin. Twenty six plates in lateral line. Lip gross, ovate and with numerous small papillae; labial barbel short and broad, with no membrane between barbel and lip. Premaxilla with 65-89 and dentary with 64-90 thin and elongate teeth; internal cusp of each tooth shorter than external.

Color pattern. Ground color of head, trunk and fins dark brown uniform; light brown in lower abdomen. Head, trunk and fins spotted with minute pale spots mainly along plates and interradial membranes; series of pale spots also on median region of each trunk plate, in some specimens forming rows of pale spots more conspicuous on caudal peduncle base. All fins dark brown; branched rays of pectoral, pelvic and lower lobe of caudal fin light brown; distal region of caudal fin bounded with pale brown pigment.

Distribution. Known from rio Iguaçu, Paraná State, Brazil. Hypostomus myersi is widely distributed along the rio Iguaçu and it is also found in tributaries flowing into this river as the rio Areia, Cavernoso, Cotegipe, Guarani, Jordão, córrego da divisa, among others. However, it was not usually found in the small headwater streams as is the case of $H$. derbyi.

\section{Hypostomus nigropunctatus new species Fig. 7}

Holotype. MZUSP 106072, 184,4 mm SL, rio Iguaçu, Salto Segredo reservoir, Brazil, Paraná State, Municipality of Mangueirinha/ Reserva do Iguaçu, 2546’45”S 5207’00”W, 3 Feb 1995, Nupélia.

Paratypes. All from Brazil. Paraná State. LBP 9214, 1, 232.9 mm SL, rio Jordão (at its mouth), Municipality of Reserva do Iguaçu, 2546'21”S 5207’04”W, 8 Nov 1999, J. D. Latini. LISDEBE, 1, 204.0 mm SL, rio Butiá, Municipality of Mangueirinha, 2559'23”S 5204’39”'W, 5 Nov 1994, Nupélia. MHNCI 12328, 1, 178.1 mm SL, rio Covó, Municipality of Mangueirinha, 2558'13”S 5209'10”W, 3 Feb 1996, Nupélia. NUP 5081, 1, 84.3 mm SL; downstream Salto Segredo reservoir, rio Iguaçu, Municipality of Mangueirinha/Reserva do Iguaçu, 254'ㅇ 5205’W, 3 Feb 1995, Nupélia. NUP 5082, 1, 171.4 mm SL, rio Jordão (at its mouth), Municipality of Reserva do Iguaçu, 2546'17”'S 5206'51”'W, 26 Nov 1996, Nupélia. NUP 5083, 1, 208.4 mm SL, rio Covó, Municipality of Mangueirinha, 2558'13”S 5209'10”W, 3 Dec 1993, Nupélia. NUP 5084, 2, 224.0-230.0 mm SL, rio Covó, Municipality of Mangueirinha, 2558'13”S 5209'10”W, 4 Feb 1994, Nupélia. NUP 5085, 1, 200.5 mm SL, rio Covó, 2558'13”S 5209'10”W, Municipality of Mangueirinha, 3 Feb 1999, Nupélia. NUP 7518, 1, 173.8 mm SL, rio Covó, Municipality of Mangueirinha, 2558’13”S 5209’10”W, 4 Feb 1994, Nupélia. NUP 7519, 1, 224.0 mm SL, rio Covó, Municipality of Mangueirinha, 2558'13"S 5209’10”W, 2 Dec 1994, Nupélia. ZSM 34136, 1, 176.1 mm SL, rio Covó, 2558'13”S 5209'10”W, Municipality of Mangueirinha, 4 Feb 1995, Nupélia.

Diagnosis. Hypostomus nigropunctatus can be distinguished from the species of the $H$. cochliodon group, except $H$. hemicochliodon, by having bifid non spoon-shaped teeth and with the lateral cups not fused to the mesial one (vs. 
spoon-shaped teeth with lateral cups usually fused to the mesial one). From $H$. alatus, $H$. albopunctatus, $H$. chrysostiktos, $H$. faveolus, $H$. francisci, $H$. lexi, $H$. luteus, $H$. luteofrenatus, $H$. margaritifer, $H$. microstomus, $H$. multidens, $H$. regani, $H$. roseopunctatus, $H$. scaphiceps, $H$. strigaticeps, $H$. tietensis and $H$. variipictus it is distinguished by having dark spots over body and fins (vs. pale spots). It is distinguished from the remaining congeners, except $H$. agna,
$H$. brevicauda, $H$. brevis, $H$. derbyi, $H$. garmani, $H$. goyazensis, $H$. heraldoi, $H$. hermanni, $H$. iheringii, $H$. johnii, $H$. lima, $H$. luetkeni, $H$. macrops, $H$. nigromaculatus, $H$. ternetzi, $H$. topavae and $H$. wuchereri, by the absence of keels on pterotic-supracleitrhum, pre-dorsal plates and on lateral series of plates (vs. having moderate to developed keels on pterotic-supracleitrhum, pre-dorsal plates, and lateral series of plates). From $H$. agna, $H$. brevicauda, $H$. heraldoi, $H$.

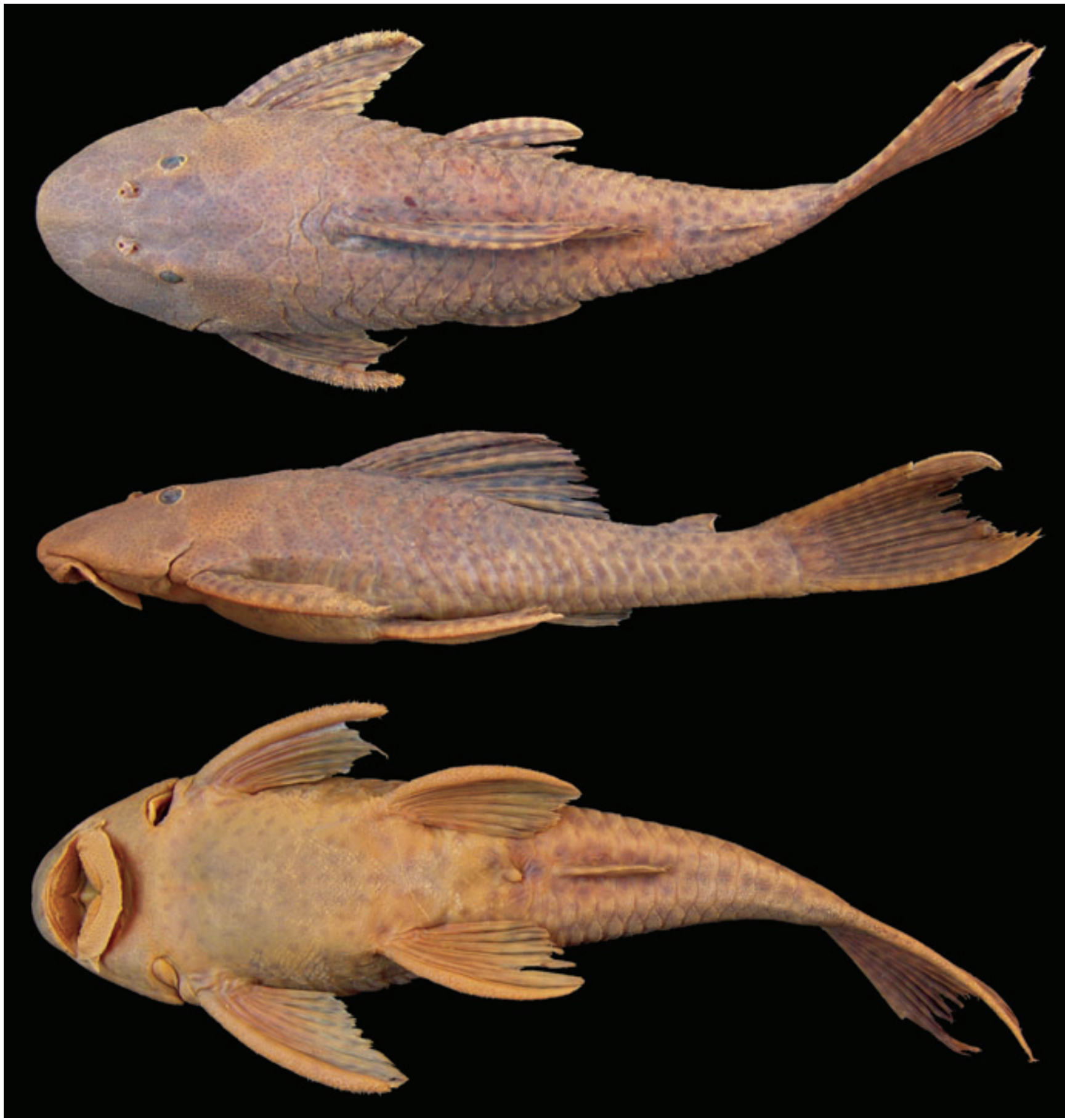

Fig. 7. Holotype of Hypostomus nigropunctatus n. sp., MZUSP 106072, 184.4 mm SL, rio Iguaçu, Municipality of Mangueirinha/ Reserva do Iguaçu, Paraná, Brazil. 
Table 1. Morphometric data and counts of Hypostomus albopunctatus, H. commersoni and $H$. derbyi from the rio Iguaçu basin, Brazil. SD = standard deviation.

\begin{tabular}{|c|c|c|c|c|c|c|c|c|c|}
\hline & \multicolumn{3}{|c|}{$\begin{array}{l}\text { H. albopunctatus } \\
\mathrm{n}=20\end{array}$} & \multicolumn{3}{|c|}{$\begin{array}{l}\text { H. commersoni } \\
\mathrm{n}=20\end{array}$} & \multicolumn{3}{|c|}{$\begin{array}{l}\text { H. derbyi } \\
\mathrm{n}=20\end{array}$} \\
\hline & Range & Mean & SD & Range & Mean & SD & Range & Mean & SD \\
\hline Standard length & $78.7-226.0$ & $\begin{array}{r}145.5 \\
\text { Percent }\end{array}$ & $\begin{array}{l}47.98 \\
\text { f SL }\end{array}$ & $131.5-283.0$ & 204.9 & 39.27 & $131.2-268.2$ & 184.0 & 32.64 \\
\hline Pre-dorsal distance & $40.3-46.3$ & 42.8 & 1.38 & $35.9-50.2$ & 38.8 & 3.07 & 30.2-39.4 & 36.9 & 2.51 \\
\hline Head length & $32.2-38.4$ & 34.6 & 1.43 & 28.2-38.5 & 30.7 & 2.82 & 27.6-33.5 & 30.5 & 1.38 \\
\hline Cleithral width & $30.9-33.2$ & 31.7 & 0.62 & 26.6-35.7 & 28.3 & 1.63 & 25.8-30.4 & 27.8 & 1.24 \\
\hline Head depth & $15.5-18.8$ & 17.1 & 0.75 & $16.8-24.8$ & 19.3 & 1.63 & 16.3-19.7 & 18.0 & 0.98 \\
\hline Interdorsal length & 15.4-18.6 & 17.0 & 0.92 & $13.2-29.6$ & 19.3 & 1.63 & 19.4-24.9 & 21.4 & 1.42 \\
\hline Caudal-peduncle length & 29.3-32.4 & 30.3 & 0.93 & 23.6-33.7 & 30.2 & 1.99 & 31.8-38.5 & 34.4 & 1.46 \\
\hline Caudal-peduncle depth & 10.1-11.1 & 10.7 & 0.34 & 8.9-10.4 & 9.4 & 0.42 & 8.1-9.6 & 8.7 & 0.32 \\
\hline Dorsal-spine length & $20.8-27.6$ & 25.0 & 1.61 & $32.6-45.0$ & 36.4 & 3.08 & 23.7-30.3 & 26.4 & 1.55 \\
\hline Thoracic length & $20.1-26.4$ & 14.2 & 1.53 & $24.7-29.4$ & 27.1 & 1.34 & $20.2-26.7$ & 24.2 & 1.53 \\
\hline \multicolumn{10}{|c|}{ Percents of head length } \\
\hline Cleithral width & 84.4-97.5 & 91.8 & 3.71 & 88.0-96.7 & 92.1 & 2.30 & $86.5-100.2$ & 91.3 & 3.51 \\
\hline Head depth & 46.3-53.2 & 49.7 & 2.13 & $56.9-66.7$ & 63.0 & 2.80 & $52.5-66.8$ & 59.1 & 3.92 \\
\hline Snout length & $62.8-69.9$ & 67.0 & 1.70 & $57.1-65.4$ & 60.9 & 2.02 & $57.0-63.2$ & 60.4 & 1.66 \\
\hline Orbital diameter & $11.2-16.1$ & 13.3 & 1.28 & 11.4-14.3 & 12.9 & 0.90 & 11.9-15.0 & 12.9 & 0.86 \\
\hline Interorbital width & 28.8-31.1 & 30.9 & 1.75 & $36.6-42.9$ & 39.6 & 1.76 & 32.3-38.3 & 34.8 & 1.95 \\
\hline Mandibular width & $17.2-22.5$ & 19.6 & 1.60 & $10.4-16.0$ & 14.7 & 1.29 & $15.5-19.7$ & 17.8 & 1.02 \\
\hline \multicolumn{10}{|c|}{ Other percents } \\
\hline Snout length/orbital diameter & $16.0-24.9$ & 20.0 & 2.30 & 18.4-25.0 & 21.2 & 1.74 & $19.7-26.3$ & 21.3 & 1.68 \\
\hline Interorbital width/orbital diameter & 32.9-50.0 & 43.3 & 4.88 & 29.9-35.3 & 32.5 & 1.74 & $32.5-45.3$ & 37.1 & 2.97 \\
\hline Interorbital width/mandibular width & 49.0-75.9 & 63.6 & 7.02 & $27.5-41.8$ & 37.1 & 3.51 & $42.2-57.7$ & 51.4 & 4.89 \\
\hline Pre-dorsal length/first dorsal-fin length & 49.6-62.9 & 58.7 & 3.45 & $81.0-111.3$ & 94.2 & 7.12 & 64.1-86.3 & 72.2 & 5.89 \\
\hline Pre-dorsal length/first pectoral-fin length & $59.4-69.3$ & 64.6 & 2.93 & 74.1-89.4 & 81.6 & 5.15 & $68.8-92.8$ & 74.9 & 6.02 \\
\hline Pre-dorsal length/lower caudal-fin length & 64.3-84.3 & 77.2 & 5.00 & $94.0-112.0$ & 100.9 & 5.05 & $81.5-107.0$ & 90.4 & 7.38 \\
\hline Caudal-peduncle depth/adipose-fin length & $63.2-82.9$ & 74.3 & 4.99 & $57.8-83.3$ & 73.8 & 6.30 & 70.1-96.1 & 85.2 & 7.70 \\
\hline Caudal-peduncle length/caudal-peduncle depth & $32.2-37.7$ & 35.2 & 1.31 & $27.7-44.0$ & 31.2 & 3.42 & 23.4-27.6 & 25.3 & 1.24 \\
\hline Cleithral width/mandibular width & $18.0-25.2$ & 21.4 & 1.90 & 11.3-17.6 & 15.9 & 1.39 & $17.0-22.0$ & 19.5 & 1.36 \\
\hline Dorsal-fin base length/interdorsal length & 65.8-83.8 & 74.1 & 5.58 & $44.2-82.6$ & 66.5 & 9.91 & $81.2-104.3$ & 92.0 & 7.50 \\
\hline Lower lip length/lower lip width & 23.1-35.4 & 29.5 & 2.80 & 24.3-33.5 & 28.5 & 2.30 & 23.6-34.7 & 28.4 & 2.87 \\
\hline Counts & Range & Mode & SD & Range & Mode & SD & Range & Mode & SD \\
\hline Median plates series & $26-27$ & 26 & 0.37 & $27-30$ & 29 & 0.89 & $28-30$ & 28 & 0.62 \\
\hline Pre-dorsal plates & 3-3 & 3 & - & 3 & 3 & & 3 & 3 & 0 \\
\hline Plates bordering supraoccipital & $1-1$ & 1 & _- & $1-3$ & 1 & 0.84 & $1-4$ & 1 & 1.05 \\
\hline Dorsal plates below dorsal-fin base & $7-8$ & 7 & 0.49 & $8-10$ & 9 & 0.40 & $7-8$ & 8 & 0.22 \\
\hline Plates between dorsal and adipose fin & 6-7 & 7 & 0.50 & $7-8$ & 8 & 0.42 & $7-9$ & 8 & 0.49 \\
\hline Plates between adipose and caudal fin & 4-5 & 5 & 0.22 & 4-6 & 5 & 0.46 & 5-6 & 5 & 0.44 \\
\hline Plates between end of anal-fin base and caudal fin & $12-13$ & 12 & 0.41 & $13-15$ & 13 & 0.61 & $13-15$ & 14 & 0.52 \\
\hline Premaxillary teeth & $26-51$ & 28 & 7.21 & $23-48$ & 41 & 6.40 & $21-42$ & 40 & 6.01 \\
\hline Dentary teeth & $26-44$ & 33 & 4.87 & $24-53$ & 39 & 6.89 & $23-43$ & 30 & 5.30 \\
\hline
\end{tabular}

hermanni, H. garmani, H. johnii, H. luetkeni, $H$. nigromaculatus, $H$. vermicularis, and $H$. wuchereri by having deeper body and a pair of parallel moderate keels on predorsal plates (vs. depressed body without keels on pre-dorsal plates). From H. brevis, H. goyazensis, H. johnii, H. iheringii, $H$. lima, $H$. ternetzi, and $H$. topavae by having abdomen completely plated ( $v$ s. abdomen naked in $H$. brevis and partially plated in $H$. goyazensis, $H$. iheringii, $H$. kuarup, $H$. johnii, $H$. lima, $H$. macrops, $H$. ternetzi, and $H$. topavae). From $H$. derbyi by having small-sized and close-settled dark spots (equal to smaller than eye pupil) on dorsal region of head, trunk, and fins (vs. middle-sized and moderate-settled dark spots (approximately equal to eye diameter length) on dorsal region of head, trunk, and fins); and by having three pre-dorsal plates bordering supraoccipital (vs. usually one plate).

Description. Dorsal profile of head slightly concave from tip of snout to supraoccipital; supraoccipital elevated and forming an inconspicuous keel; pre-dorsal plates slightly concave. Head elevated and slightly compressed, totally covered by plates with fine odontodes. A conspicuous keel subsequent to pterotic-supracleithrum region behind orbit, conspicuously followed by subsequent trunk plates to caudal peduncle; a divergent keel on median portion of supraoccipital, running by dorsal plate series to caudal fin, giving to dorsal region of caudal peduncle a slightly quadrangular aspect. Snout narrow and compressed covered by irregular series of small plates; an inconspicuous keel running from snout tip to upper region of orbit. Orbits elevated, positioned nearly lateral; orbital diameter $10.9-12.5 \%$ in head length. Posterior region of head covered by two unpaired elongate plates between supraoccipital and dorsal-fin insertion; an unpaired nuchal plate enclose first dorsal-fin spinelet. Supraoccipital and pterotic-supracleithrum densely covered by odontodes mainly along keels. Nare large, its diameter nearly twice in intranasal distance. Dorsal profile of trunk slightly declining from dorsal-fin insertion to caudal 
Table 2. Morphometric data and counts of Hypostomus myersi and H. nigropunctatus n. sp. from the rio Iguaçu basin, Brazil. $\mathrm{SD}=$ standard deviation

\begin{tabular}{|c|c|c|c|c|c|c|c|}
\hline & \multicolumn{3}{|c|}{$\begin{array}{l}\text { H. myersi } \\
\mathrm{n}=20\end{array}$} & \multicolumn{4}{|c|}{$\begin{array}{l}\text { H. nigropunctatus } \\
\mathrm{n}=13\end{array}$} \\
\hline & Range & Mean & $\mathrm{SD}$ & Holotype & Range & Mean & $\mathrm{SD}$ \\
\hline Standard length & $108.4-214.1$ & 146.3 & 33.36 & 184.4 & $171.4-232.9$ & 200.2 & 22.44 \\
\hline \multicolumn{8}{|c|}{ Percents of SL } \\
\hline Pre-dorsal distance & $35.6-43.0$ & 39.7 & 1.83 & 37.9 & 35.4-38.6 & 36.8 & 1.08 \\
\hline Head length & $28.8-35.2$ & 32.3 & 1.77 & 31.1 & 28.4-32.2 & 30.0 & 1.13 \\
\hline Cleithral width & $28.5-33.8$ & 31.5 & 1.31 & 28.4 & $25.1-29.5$ & 26.9 & 1.14 \\
\hline Head depth & $16.3-20.4$ & 18.2 & 1.04 & 18.7 & $15.9-20.2$ & 17.1 & 1.22 \\
\hline Interdorsal length & $12.4-16.7$ & 14.5 & 1.23 & 21.0 & $20.5-23.0$ & 21.9 & 0.86 \\
\hline Caudal-peduncle length & 29.7-35.3 & 32.2 & 1.23 & 32.5 & $32.0-36.2$ & 34.2 & 1.35 \\
\hline Caudal-peduncle depth & $9.9-11.3$ & 10.5 & 0.41 & 9.0 & 8.4-9.0 & 8.8 & 0.21 \\
\hline Dorsal-spine length & 24.3-34.4 & 28.6 & 2.72 & 27.9 & 26.9-31.0 & 29.2 & 1.26 \\
\hline Thoracic length & $22.1-25.7$ & 24.1 & 1.02 & 25.3 & $21.5-25.3$ & 23.5 & 1.04 \\
\hline \multicolumn{8}{|c|}{ Percents of head length } \\
\hline Cleithral width & 93.6-103.2 & 97.6 & 3.10 & 91.3 & 85.9-92.2 & 89.6 & 1.80 \\
\hline Head depth & $53.2-60.8$ & 56.5 & 2.24 & 60.1 & $53.6-62.7$ & 56.9 & 2.54 \\
\hline Snout length & $59.0-66.1$ & 62.8 & 2.14 & 62.5 & $56.2-62.6$ & 60.6 & 1.71 \\
\hline Orbital diameter & $14.6-21.7$ & 18.2 & 2.28 & 12.2 & $10.9-12.5$ & 11.7 & 0.45 \\
\hline Interorbital width & $30.7-36.5$ & 34.0 & 1.46 & 35.7 & $32.0-36.4$ & 34.0 & 1.39 \\
\hline Mandibular width & $21.2-24.5$ & 23.0 & 1.06 & 18.3 & $17.5-18.9$ & 18.2 & 0.44 \\
\hline \multicolumn{8}{|c|}{ Other percents } \\
\hline Snout length/orbital diameter & $23.0-36.0$ & 29.1 & 4.35 & 19.5 & $18.5-20.3$ & 19.3 & 0.56 \\
\hline Interorbital width/orbital diameter & 42.6-68.3 & 53.8 & 8.24 & 34.1 & $33.0-36.8$ & 34.5 & 1.29 \\
\hline Interorbital width/mandibular width & 61.9-75.2 & 67.8 & 3.62 & 51.2 & 48.3-57.7 & 53.7 & 2.63 \\
\hline Pre-dorsal length/first dorsal-fin length & $65.1-84.3$ & 71.9 & 5.36 & 73.8 & 73.8-86.6 & 79.5 & 3.86 \\
\hline Pre-dorsal length/first pectoral-fin length & $71.3-90.1$ & 81.1 & 5.26 & 69.6 & $69.6-84.7$ & 77.3 & 4.05 \\
\hline Pre-dorsal length/lower caudal-fin length & 72.3-86.4 & 77.6 & 3.48 & 82.7 & 82.6-94.8 & 89.3 & 4.26 \\
\hline Caudal-peduncle depth/adipose-fin length & 84.5-107.0 & 94.2 & 5.41 & 77.1 & 75.9-97.9 & 84.0 & 6.53 \\
\hline Caudal-peduncle length/caudal-peduncle depth & 29.3-37.4 & 32.7 & 2.24 & 27.7 & 23.8-27.7 & 25.6 & 1.13 \\
\hline Cleithral width/mandibular width & $21.8-25.7$ & 23.6 & 1.14 & 20.0 & 19.0-21.3 & 20.3 & 0.62 \\
\hline Dorsal-fin base length/interdorsal length & $46.7-66.3$ & 53.4 & 5.76 & 82.5 & 82.5-103.9 & 93.0 & 6.53 \\
\hline Lower lip length/lower lip width & $20.8-29.7$ & 25.5 & 2.64 & 27.0 & 26.4-33.1 & 29.5 & 2.10 \\
\hline Counts & Range & Mode & $\mathrm{SD}$ & Holotype & Range & Mode & $\mathrm{SD}$ \\
\hline Median plates series & $24-27$ & 26 & 0.67 & 28 & $27-30$ & 28 & 0.80 \\
\hline Pre-dorsal plates & 3 & 3 & 0.0 & 3 & 3 & 3 & - \\
\hline Plates bordering supraoccipital & $1-1$ & 1 & - & 3 & 3 & 3 & - \\
\hline Dorsal plates below dorsal-fin base & $1-3$ & 1 & 0.67 & 3 & $7-8$ & 8 & 0.55 \\
\hline Plates between dorsal and adipose fin & $4-6$ & 5 & 0.55 & 8 & $7-8$ & 8 & 0.38 \\
\hline Plates between adipose and caudal fin & $4-5$ & 4 & 0.31 & 5 & 5-6 & 5 & 0.44 \\
\hline Plates between end of anal-fin base and caudal fin & $12-14$ & 13 & 0.59 & 13 & $13-15$ & 14 & 0.49 \\
\hline Premaxillary teeth & $65-89$ & 82 & 6.15 & 36 & $32-38$ & 33 & 2.42 \\
\hline Dentary teeth & $64-90$ & 76 & 7.43 & 36 & $29-43$ & 36 & 3.45 \\
\hline
\end{tabular}

fin. Adipose-fin spine large and situated seven plates after dorsal-fin insertion. Anterior plates of longitudinal trunk series after scapular bridge with a conspicuous keel. Maximum width at scapular bridge gradually decreasing to caudal fin. Dorsal fin II,7; dorsal-fin insertion at two plates before vertical through pelvic-fin insertion; not reaching adipose-fin spine; its distal margin convex. Pectoral fin I,6 rays; unbranched ray elongate, with large odontodes on distal margin; surpassing pelvic-fin insertion when adpressed; its distal margin almost straight. Pelvic fin i,5 rays; posterior margin truncate; unbranched ray reaching or surpassing anal-fin insertion. Anal fin, i,5; distal border slightly rounded. Caudal fin i,14,i rays, slightly notched; lower lobe longer than upper.

Body covered by five lateral series of plates not forming conspicuous keels; odontodes more concentrated along keeled areas of integument. Rostral margin of snout aciculate; ventral view of labial insertion deeply notched. Snout tip formed by junction of upper lip that is covered by irregular series of small plates; odontodes restricted to plated area extending from upper supraoccipital to distal pteroticsupracleithrum. Scapular bridge totally covered by skin and small plates with minute odontodes covering nearly all abdomen; naked areas only in front of pelvic-fin insertion; two pair of narrow plates between anal-fin insertion and anus. Twenty eight plates in lateral line. Lips and oral region semicircular with dense papillae; labial barbel short and free from labial margin. Premaxilla with 32-38 and dentary with 2943 fine and short teeth with cusps nearly equal in size.

Color pattern. Ground color of head and trunk dark brown uniform; dorsal region of head and trunk densely spotted with fine black spots. Interradial membranes of all fins excepting caudal fin intermittent black spotted; unbranched rays of all fins light brown uniform; black spotted intermittent 
from space to space on upper region and light brown in lower regions. Unbranched rays and interradial membranes of caudal fin black spotted, forming six transversal black bars crossing both lobes of caudal fin. Abdominal region light brown, irregularly black spotted or vermiculated on whole abdomen and lower caudal peduncle. Unbranched ray of pectoral, pelvic, anal and caudal fins light brown in lower regions but black spotted on upper regions.

Distribution. Known from rio Iguaçu, Paraná State, Brazil. Hypostomus nigropunctatus is known from the middle stretches of the rio Iguaçu, at Salto Segredo reservoir and at the mouth of rios Covó and Jordão.

\section{Discussion}

This article deals with redescriptions and comparisons between the rio Iguaçu species (Fig. 8) and those from rio Paraná. Despite the Hypostomus species from Iguaçu probably remained in considerable isolation from the Paranean species by the Iguaçu falls, only $H$. derbyi and Hypostomus nigropunctatus $\mathrm{n}$. sp. seems to be actually restricted to Iguaçu river basin. The species identified by Miquelarena et al. (1997) as H. derbyi from arroyo Urugua-í is herein put in doubt. Some populations of $H$. ancistroides Ihering, a widespread species from the upper rio Paraná basin, could be misidentified as $H$. derbyi. Besides, usually reaching a smaller length than $H$. derbyi, $H$. ancistroides has more prominent keels on compound pterotic-supracleitrum and along lateral series of plates. Hypostomus derbyi has also an exclusive combination of characters as dark-spotted trunk, compressed head and body without keels on lateral plate series. Some other morphologically similar species as $H$. agna, $H$. isbrueckeri, $H$. interruptus and

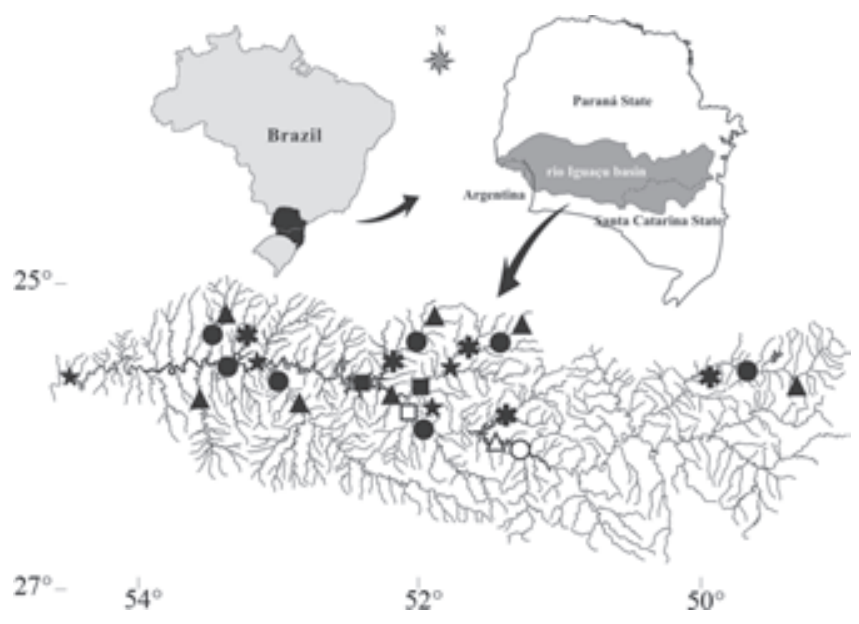

Fig. 8. Geographic distribution of the five species of Hypostomus in the rio Iguaçu basin. Hypostomus albopunctatus (star), H. commersoni (asterisk), H. derbyi (triangle), H. myersi (dot) and $H$. nigropunctatus (square). Open symbols are the type localities.
H. luetkeni have more evident depressed head and body. On the other hand, Hypostomus nigropunctatus n. sp. combines some characteristics of $H$. derbyi but with a more numerous and fine-closed dark spots on head and three plates bordering supraoccipital (vs. usually one in $H$. derbyi).

Hypostomus myersi, which occurs at rio Iguaçu, upper and downstream of the Iguaçu Falls is detached by its exclusive association of head and trunk depressed, dental formulae 65 to 89 on premaxillar and 64 to 90 teeth on dentary, and distinctive ground color dark brown, combined with pale vermiculations and punctuations. This combination of characters makes $H$. myersi very easy to be recognized among the species of rio Paraná basin. Hypostomus derbyi and H. myersi whereas very common at rio Iguaçu basin, they are currently unregistered in the upper rio Paraná basin. This fact was also recognized by Gomes et al. (1990) concerning to Iguaçu at Argentina.

From the nominal species from the rio Iguaçu, only Hypostomus albopunctatus and H. commersoni were also registered in the upper rio Paraná basin. Hypostomus albopunctatus, show the head and trunk strong depressed, combined with a robust teeth design with internal cusps about twice in length than the external cusp; and color pattern dark brown with numerous circular to semicircular pale spots. However, the pectoral-fin spine equal to shorter than the pelvic-fin unbranched ray is the main character to differ $H$. albopunctatus from the other species of Hypostomus. Hypostomus commersoni from rio Iguaçu is also very different from its congeners from rio Paraná, characterized by lateral series of plates ending in pungent keels, mainly those on the lateral line. Also, its slender and long teeth in the premaxilla (23 to 48) and in dentary (24 to 53), the exclusive reddish color pattern, and the three plates bordering supraoccipital are the distinctive features for $\mathrm{H}$. commersoni. Therefore, while the $H$. derbyi and $H$. nigropunctatus might be considered exclusive from the rio Iguaçu, $H$. albopunctatus, $H$. myersi and H. commersoni occur in other tributaries of rio Paraná.

The general pattern of rio Iguaçu basin, according to Petri \& Fúlfaro (1983) is similar to those of Paraná basin, aged from Mesozoic times. Otherwise, some tributary rivers of Iguaçu were likely established during Tertiary. This supposition is due to intense tectonic activities that among other events formed the Iguaçu Falls in rio Iguaçu and the Sete Quedas Falls in rio Paraná (this last fall is currently covered by waters of the Itaipu hydroelectric Dam). Following Petri \& Fúlfaro (1983), in both cases the tectonic elevation was nearly one hundred meters, isolating both the rio Iguaçu and upper rio Paraná basins from the lower stretches of the rio Paraná, which resulted in three ichthyofaunistic areas.

As the Neotropical ichthyofauna is normally older than those geological events, we may comfortably understand a former consensus between the Iguaçu and Paraná basins. On the other hand, by the characteristic geographic isolation imposed for Iguaçu basin in relation to upper rio Paraná basin by the rising of the large falls in Tertiary times, we may believe that the species of Hypostomus, alike other endemic fish groups of the rio Iguaçu, present some relevant degree of endemism. 
Comparative material. Argentina. Hypostomus cordovae: BMNH 1878.4.4.1, 178.3 mm SL, holotype, rio Paraná, Cordova. Hypostomus laplatae (= H. taeniatus): BMNH 1908.8.29.17, 207.3 mm SL, syntype, rio La Plata. Brazil. Hypostomus affinis: NUP 9663, 2, 267.5-301.2 mm SL, rio Paraibuna, Minas Gerais State. Hypostomus ancistroides: MZUSP 2131, 4, 95.6-165.1 mm SL, rio Tatuí, São Paulo State. Hypostomus denticulatus: MZUSP 98770, 161.9 mm SL, holotype, rio do Peixe, Goiás State. Hypostomus heraldoi: MZUSP 98771, 217.9 mm SL, holotype, rio Pirapitinga, Goiás State. Hypostomus interruptus: MZUSP 2110, 119.5 mm SL, holotype, rio Juquiá, São Paulo State. Hypostomus isbrueckeri: MZUSP 40257, 2, 172.3-176.6 mm SL, syntypes, rio Uruguai, Rio Grande do Sul State. Hypostomus punctatus: MHNG 2014.056, 219.3 mm SL, H. subcarinatus: MNHN A.9575, 241.8 mm SL, holotype. Hypostomus tapijara: NUP 2795, 3, 174.9-193.2 mm SL, rio Capivari, Paraná State. Paraguay. Hypostomus dlouhyi: MHNG 2229.43, 139.5 mm SL, holotype, rio Yguazú (non Iguaçú). Hypostomus piratatu: MHNG 2265.03, 214.0 mm SL, holotype, dep. Paraguari. Uruguay. Hypostomus commersoni: MNHN A.9444, $425.0 \mathrm{~mm} \mathrm{SL}$, holotype, rio de la Plata. A more complete list of comparative examined material is that of Jerep et al. (2007).

\section{Acknowledgements}

The authors are indebted to Barbara Brown (AMNH), Mary A. Rogers of Field Museum of Natural History (FMNH), Claude Weber and Sonia F. Muller (MHNG), Mark SabajPerez (ANSP), Osvaldo T. Oyakawa (MZUSP), Patrick Campbell (BMNH), Patrice Pruvost (MNHN), Vinícius Abilhoa (MHNCI) and Zilda M. S. Lucena (MCP) for loan of comparative material and hosting museum visits; Renata Ota (UEM-NUP) and Vinícius Abilhoa (MNHCI) for helping with collection data information. Alexandre K. de Oliveira helped with cataloguing specimens at laboratory. Copel and Nupélia provided logistical support in some fieldwork. This study was supported by funds and grants from the Conselho Nacional de Desenvolvimento Científico e Tecnológico (CNPq) for JCG, HAB, and CHZ. CHZ was supported by grants from the US National Foundation (DEB-0315963) through the project entitled Planetary Biodiversity Inventory: All Catfish Species (Siluriformes), Phase I of an Inventory of the Otophysi to visit museums, and JCG from the Robert O. Bass Visitor Fund of FMNH to visit the Field Museum of Natural History.

\section{Literature Cited}

Bifi, A. G., D. Baumgartner, G. Baumgartner, V. A. Frana \& T. Debona. 2006. Composição específica e abundância da ictiofauna do rio dos Padres, bacia do rio Iguaçu, Brasil. Acta Scientiarum Biological Science, 28: 203-211.

Baumgartner, D., G. Baumgartner, C. S. Pavanelli, P. R. L. da Silva, V. A. Frana, L. C. de Oliveira \& M. R. Michelon. 2006. Fish, Salto Osório Reservoir, Iguaçu River basin, Paraná State, Brazil. Check List, 2: 1-4.

Boeseman, M. 1968. The genus Hypostomus Lacépède, 1803 and its Surinam representatives (Siluriformes, Loricariidae). Zoologische Verhandelingen, 99: 1-89.
Carvalho, M. \& F. A. Bockmann, 2007. Família Loricariidae: Hypostominae. Pp. 91-98. In: Buckup, P. A., N. A. Menezes \& M. S. Ghazzi (Eds.). Catálogo de peixes de água doce do Brasil. Museu Nacional, Rio de Janeiro, 195p.

Eigenmann, C. H. 1910. Catalogue of the fresh-water fishes of tropical and south temperate America. Reports of the Princeton University expeditions to Patagonia 1896-1899. Zoology: 375511.

Fowler, H. W. 1954. Os Peixes de Água Doce do Brasil (4 entrega). Arquivos de Zoologia. São Paulo, IX, IX+400 pp.

Garavello, J. C., C. S. Pavanelli \& H. I. Suzuki. 1997. Caracterização da ictiofauna do rio Iguaçu. Pp. 61-84. In: Agostinho, A. A. \& L. C. Gomes (Eds.). Reservatório de Segredo: bases ecológicas para o manejo. Maringá: EDUEM, Maringá.

Gomez, S. E., H. L. López \& N. I. Toresani. 1990. Hypostomus derbyi (Haseman) y Hypostomus myersi (Gosline), descripción complementaria y primeros registros para Argentina (Pisces, Loricariidae). Studies on Neotropical Fauna and Environment, 25: 139-152.

Gómez, S. \& D. Somay. 1989. La Ictiofauna del Parque Nacional Iguazú (Argentina). II. Pariolius hollandi e Hypostomus albopunctatus, primeras citas para Argentina (Pisces, Siluriformes). Limnobios, 2: 725-728.

Gosline, W. A. 1945. Catálogo dos Nematognathos de água doce da América do Sul e Central. Boletim do Museu Nacional, nova série, Zoologia, 33: 1-138.

Gosline, W. A. 1947. Contributions to the Classification of the Loricariid Catfishes. Arquivos do Museu Nacional: 77-134.

Günther, A. 1864. Catalogue of the fishes in the British Museum. Vol. 5. Catalogue of the Physostomi, containing the families Siluridae, Characinidae, Haplochitonidae, Sternoptychidae, Scopelidae, Stomiatidae in the collection of the British Museum. London, Trustees, 455p.

Haseman, J. D. 1911. Some new species of fishes from the rio Iguassu. Annals of the Carnegie Museum, 7: 374-387.

Ihering, R. v. 1905. Descriptions of four new loricariid fishes of the genus Plecostomus from Brazil. Annals of Magazine and Natural History, 7: 558-561.

Ihering, R. v. 1911. Algumas espécies novas de peixes de água doce (Nematognatha) (Corydoras, Plecostomus, Hemipsilichthys). Revista do Museu Paulista, 8: 380-404.

Ingenito, L. F. S., L. F. Duboc \& V. Abilhoa. 2004. Contribuição ao conhecimento da ictiofauna da bacia do alto rio Iguaçu, Paraná, Brasil. Arquivos de Ciências Veterinárias e Zoológicas UNIPAR, 7: 23-36.

Isbrucker, I. J. H. 1980. Classification and Catalogue of the Mailed Loricariidae (Pisces, Siluriformes). Instituut voor Taxonomische Zoölogie (Zoölogisch Museum), Amsterdam, 181p.

Jerep, F. C., O. A. Shibatta \& C. H. Zawadzki. 2007. A new species of Hypostomus Lacépède, 1803 (Siluriformes: Loricariidae) from the upper rio Paraná basin, southern Brazil. Neotropical Ichthyology, 5: 435-442.

López, H. L. \& A. M. Miquelarena. 1991. Los Hypostominae (Pisces, Loricariidae) de Argentina. Contribución Científica $n^{\circ} 500$ del Instituto de Limnologia "Raul A. Ringuelet”, $64 p$.

Maack, R. 1981. Geografia Física do Estado do Paraná. Rio de Janeiro: Livraria José Olympio Editora, Rio de Janeiro, 2ª ed., 153p.

Marini, T., J. T. Nichols \& F. Lamonte. 1933. Six new eastern South American fishes, examined in the American Museum of Natural History. American Museum Novitates, 618: 1-7. 
Miquelarena, A. M., L. C. Protogino \& H. L. López. 1997. Fishes from the Arroyo Urugua-í (upper Parana basin, Misiones, Argentina) before impoundment of the dam. Revue Française de Aquariologie, 24: 65-72.

Miranda Ribeiro, A. 1907. Peixes do Iporanga - S. Paulo. Resultados de excursões do Sr. Ricardo Krone, membro correspondente do Museu Nacional do Rio de Janeiro. A Lavoura, Boletim da Sociedade Nacional de Agricultura, 11: 185-190.

Miranda Ribeiro, A. 1911. Fauna brasiliense. Peixes. Tomo IV (A) [Eleutherobranchios Aspirophoros]. Arquivos do Museu Nacional, 16: 1-504.

Miranda Ribeiro, A. 1918. Três gêneros e dezessete espécies novas de peixes brasileiros. Revista Museu Paulista, 10: 629-646.

Nichols, J. T. 1919. “Cascudos” brasileiros do gênero Plecostomus do Museu Paulista. Revista Museu Paulista, 11: 3-5 [in Portuguese], 9-10.

Oyakawa, O. T., A. Akama \& A. M. Zanata. 2005. Review of the genus Hypostomus Lacépède, 1803 from Rio Ribeira de Iguape basin, with description of a new species (Pisces, Siluriformes, Loricariidae). Zootaxa, 921: 1-27.

Petri, S. \& V. Fúlfaro. 1983. Geologia do Brasil. T. A. Queiroz Editora \& EDUSP, São Paulo, 63lp.

Regan, C. T. 1908. Descriptions of New Loricariid Fishes from South America. Proceedings of Zoological Society of London, 4: 795-800.

Severi, W. \& A. A. M. Cordeiro. 1994. Catálogo de peixes da bacia do rio Iguaçu. Curitiba: IAP/GTZ, 128p.

Schaefer, S. A. 1997. The Neotropical cascudinhos: systematics and biogeography of the Otocinclus catfishes (Siluriformes: Loricariidae). Proceedings of the Academy of Natural Sciences of Philadelphia, 148: 1-120.

Valenciennes, A. 1836. Poissons [pl. 7]. In: d’Orbigny, A. Voyage dans L’Amérique Méridionale (le Brésil, la République Orientale de l’Uruguay, la République Argentine, la Patagonie, La République du Chili, la République de Bolivia, la République du Pérou), exécuté pendant les années 1826, 1827, 1828, 1829, 1830, 1832 et 1833. Paris, Bertrand et Levrault.
Valenciennes, A. 1847. Poissons. Catalogue des principales espèces de poissons, rapportées de l'Amérique méridionale, 1-11. In: d’Orbigny, A. Voyage dans L’Amérique Méridionale (Le Brésil, la République Orientale de l’Uruguay, la République Argentine, la Patagonie, la République du Chili, la République de Bolivia, la République du Pérou), exécuté pendant lês années 1826, 1827, 1828, 1829, 1830, 1832 et 1833 . Vol. 5 (pt. 2). Paris, Bertrand et Levrault.

Weber, C. 1985. Hypostomus dlouhyi nouvelle espèce de poissonchat cuirassé du Paraguay (Pisces, Siluriformes, Loricariidae). Revue suisse de Zoologie, 92: 955-968.

Weber, C. 1986. Révision de Hypostomus boulengeri (Eigenmann \& Kennedy), et deux espèces nouvelles de poissons-chats du Paraguay (Pisces, Siluriformes, Loricariidae). Revue suisse de Zoologie, 93: 979-1007.

Weber, C. 1987. Hypostomus microstomus sp. nov. et autres poissons-chats cuirassés du Rio Parana (Pisces, Siluriformes, Loricariidae). Archives de Science (Geneva), 40: 273-284.

Weber, C. 2003. Subfamily Hypostominae. Pp. 351-372. In: Reis, R. E., S. O. Kullander \& C. J. Ferraris Jr. (Eds.). Check List of the Freshwater Fishes of South and Central America. Porto Alegre, Edipucrs, 729p.

Zawadzki, C. H., E. Renesto \& L. M. Bini. 1999. Genetic and morphometric analysis of three species of the genus Hypostomus Lacépède, 1803 (Osteichthyes: Loricariidae) from the Rio Iguaçu basin (Brazil). Revue suisse de Zoologie, 106: 91-105.

Zawadzki, C. H., M. F. P. S. Machado \& E. Renesto. 2001. Differential expression for tissue-specific isozymes in three species of the genus Hypostomus Lacépède, 1803 (Teleostei: Loricariidae). Biochemical Systematics and Ecology, 29: 911-922.

Zawadzki, C. H., E. Renesto, R. E. Reis, M. O. Moura \& R. P. Mateus. 2005. Allozyme relationships in hypostomines (Teleostei: Loricariidae) from the Itaipu reservoir, Upper Rio Paraná basin, Brazil. Genetica, 123: 271-283.

Submitted July 26, 2010

Resubmitted December 27, 2011

Accepted March 16, 2012

Published June 29, 2012 